\title{
La irrupción de las negociaciones en el Derecho administrativo: transacciones, convenios, arbitrajes ${ }^{1}$ (alerta frente a vías que informan de su posible extensión)
}

\begin{abstract}
«El acto unilateral asegura eficazmente la sumisión, pero es incapaz de suscitar el entusiasmo y el deseo de colaboración.» (E. GARCÍA DE ENTERRÍA/T. R. FERNÁNDEZ, Curso de Derecho Administrativo, I, 1993, p. 648).
\end{abstract}

Santiago González-Varas Ibáñez

Profesor Titular de Derecho administrativo

Sumario: 1. LAS ACTIVIDADES NEGOCIADAS EN EL DERECHO ADMINISTRATIVO. 2. LA POSIBILIDAD DE CONVENIR CON LOS PARTICULARES. A) Manifestaciones principales de los acuerdos procedimentales. B) Selección de un ejemplo: los convenios urbanísticos; la influencia de los intereses privados en materia urbanística (la «privatización» del urbanismo). 3. TRANSACCIONES. A) Transacción extraprocesal. B) Transacción judicial o conciliación. 4. LOS ARBITRAJES ADMINISTRATIVOS. 1. Presente y futuro del arbitraje en el Derecho administrativo. 2. Un ejemplo de regulación de los arbitrajes: el Derecho de Costa Rica. 3. El éxito del arbitraje administrativo en el ámbito del comercio internacional.

\section{LAS ACTIVIDADES NEGOCIADAS EN EL DERECHO ADMINISTRATIVO}

Cada vez más se discute acerca de las formas convencionales, de las transacciones o conciliaciones y de los arbitrajes en el Derecho administrativo. Paulatinamente van afianzándose al mismo tiempo que va surgiendo la necesidad de ir perfilando sus límites jurídicos. Es éste además un tema de indudable alcance práctico en toda Hispanoamérica, llegándose en ciertos Estados americanos a planteamientos más «progresistas» que en Europa.

El reto o ideal parece estar en lograr una sabia combinación que aglutine las ventajas que aquéllas presentan, evitando al mismo tiempo los riesgos que conllevan.

${ }^{1}$ El presente trabajo es, asimismo, una conferencia en Costa Rica que tuvo lugar el día 15 de noviembre de 2001 y será parte del libro homenaje al profesor venezolano Brewer-Carías. 
En principio, dichas formas suponen una desviación frente a los cauces clásicos o «normales» de resolución de conflictos en el Derecho administrativo, es decir, el acto unilateral con posterior recurso ante la Administración y la impugnación del acto o actuación ante la jurisdicción contencioso-administrativa.

Es claro además que su espíritu está en permitir a los agentes administrativos un cierto margen de negociación con los particulares que pueda servir para una mejor consecución de los propios intereses públicos. Y es éste precisamente un problema de fondo de estas figuras, ya que el Derecho público contemporáneo ha surgido afirmando un principio de primacía de «las leyes sobre los hombres» y no lo contrario.

Pero los convenios, las transacciones o conciliaciones y los arbitrajes presentan ventajas prácticas; por ejemplo, desde el punto de vista del logro de una mejor ejecución de la actuación administrativa por contar ésta con el previo consenso de los particulares, así como una mayor rapidez y eficacia a costa de evitar la tramitación de procedimientos o procesos innecesarios reduciendo el coste social y de tiempo que ello representa, entre otras ventajas.

De ahí que a veces se presenten conjuntamente todas las figuras mencionadas (transacciones o conciliaciones, convenios y arbitrajes), pues, aunque bien diferentes entre sí, todas ellas parecen situarse frente a ciertos problemas importantes, sociales y jurídico-administrativos, tales como la lentitud de la justicia administrativa o la conveniencia de abrir mayores cauces de participación o colaboración en favor de los ciudadanos en el ejercicio de funciones administrativas, etc.

En este sentido, las formas convencionales, por ejemplo, suelen verse como una consecuencia del creciente arraigo del Estado democrático y de la pujante participación activa de los particulares ${ }^{2}$. Así, J. TORNOS nos explica que «de la Administración autoritaria se evolucionó hacia la Administración participada (...)», aunque «la decisión final seguía siendo un acto unilateral». «La Administración convencional supone un paso más, ya no basta con ofrecer la participación, cuando se reclama que el esfuerzo por llegar a posiciones comunes se formalice. El administrado busca garantías de estabilidad en lo acordado (...). En la Administración

\footnotetext{
2 Por todos, J. C. Morón URBINA, «La solución alternativa de controversias en sede administrativa. De la imposición unilateral de la autoridad a la conciliación de intereses en asuntos administrativos», CEPSCON, Centro Peruano de Solución de Conflictos, @dministración, ciberrevista de Derecho administrativo n. $^{\circ} 12$, octubre-diciembre 1999 , www.derecho.unican.es/administracion.
} 
convencional pasamos del acto participado al acto acordado. Del acto como negocio jurídico unilateral al acto como negocio jurídico bilate$\operatorname{ral}(\ldots))^{3}$.

Sin mermar un ápice la significación de este tipo de razonamientos ${ }^{4}$, a mi juicio, la explicación última de la creciente presencia de este tipo de figuras se encontraría en la cada vez mayor presencia o incluso presión de intereses económicos en el seno del Derecho administrativo.

El arbitraje, por ejemplo, es una figura de especial desarrollo en el Derecho mercantil, hecha al modo y manera de los agentes económicos, a quienes no satisfarán las formas previstas en el Derecho administrativo para la resolución de sus conflictos con la Administración pública, representando, en cambio, el arbitraje un medio más ágil, rápido, más neutral y menos formalista y sobre todo más idóneo para resolver las cuestiones patrimoniales que a aquéllos interesan. El éxito del arbitraje, dicen J. M. Chillón Medina/J. F. Merino Merchán ${ }^{5}$, es consecuencia de la «pro-

\footnotetext{
3 Palabras de J. Tornos Mas en el prólogo a A. de Palma del Teso, Los acuerdos procedimentales en el Derecho administrativo, Valencia, 2000, autora para quien el acuerdo procedimental entre la Administración y el interesado aparece, en la actualidad, como un instrumento alternativo al tradicional acto administrativo unilateral para el ejercicio de potestades en el ámbito de la discrecionalidad. Por su parte, apunta J. ToRnos MAs: «si la Administración era autoridad y aparato prestador de servicios, hoy las principales decisiones y actividades prestacionales se desenvuelven en el mercado. La ordenación se convierte en regulación para garantizar el mercado y los clásicos servicios públicos pasan a ser servicios de interés general, es decir, actividades privadas de interés general, reguladas, pero ya no actividades propias. Esta nueva realidad no supone, sin embargo, la desaparición del Derecho administrativo (...)».
}

Véase esta obra también para un estudio de la naturaleza jurídica de los acuerdos procedimentales y sus distintas clases, así como para un análisis de los elementos de los acuerdos procedimentales, es decir, el elemento subjetivo (la Administración como parte necesaria y la posición de otros sujetos), el elemento formal (formación de los acuerdos, formalización, publicación y registro), el elemento objetivo (objeto de los acuerdos, ámbito objetivo, es decir, la discrecionalidad y contenido del acuerdo), el elemento causal (causa y fin o función) y finalmente los elementos accidentales o cláusulas accesorias (la condición, el término y el modo). Esta obra, finalmente, en el capítulo V se refiere a la visión dinámica de los acuerdos procedimentales, analizando los principios rectores de la interpretación de los acuerdos procedimentales. Asimismo, se detiene la autora en comentar las vicisitudes de la relación jurídico-administrativa surgida del acuerdo procedimental.

${ }^{4}$ Es más, cabría extender la relación hecha a las recientes reformas de la legislación administrativa que van consiguiendo erradicar la visión tradicional del administrado como un mero receptor de actos administrativos, como por ejemplo la nueva Ley de la jurisdicción contencioso-administrativa de 13 de julio de 1998 y la introducción de pretensiones procesales no impugnatorias, en las que el particular no impugna un acto, sino que requiere un acto o actuación (o prestación). Para estas cuestiones y, a su vez, su relación con la teoría de la relación jurídica puede verse mi libro Comentarios a la Ley de la jurisdicción contencioso-administrativa, Editorial Tecnos, Madrid, 1999.

5 J. M. Chillón Medina/J. F. Merino Merchán, Tratado de arbitraje privado interno e internacional, Madrid, 1991, p. 74. Esta afirmación entrecomillada se mantiene aun reconociendo las notas «publicistas del arbitraje» o la presencia del arbitraje en el Derecho procesal (p. 113 de la citada obra). 


\title{
gresiva iusmercantilización» o lo que «los mercantilistas llaman genera- lización del Derecho mercantil y comercialización del Derecho civil».
}

\begin{abstract}
Sin perjuicio de que las transacciones, los convenios y los arbitrajes pueden manifestarse en distintas ramas del Derecho ${ }^{6}$, el empuje de estas figuras estaría en la pujanza de intereses económicos ${ }^{7}$ y (en menor medida) también en el contagio de maneras políticas de actuación ${ }^{8}$.
\end{abstract}

\begin{abstract}
${ }^{6}$ Interesan ciertas referencias relativas a la presencia de la transacción tanto en el Derecho internacional público (arts. 2.3 y 33.1 de la Carta de las Naciones Unidas; J. González CAmpos y otros, Curso de Derecho internacional público, Madrid, 1992, pp. 738 y ss.), como en el Derecho laboral (recuérdense los acuerdos o convenios colectivos que resuelven un conflicto; M. Alonso OlEA/ M. E. Casas Bahamonde, Manual del Derecho del trabajo, Madrid, 1997, pp. 911 y ss.) e incluso en el Derecho penal (M. B. SAN MARTín LARRIONA, La mediación como respuesta a algunos problemas jurídico-criminológicos, Bilbao, 1997, pp. 31 y ss.) y en el propio Derecho tributario (M. L. González-Cuéllar Serrano, Los procedimientos tributarios: su terminación transaccional, Madrid, 1998, pp. 292 y ss.; véase D. Loperena Rota, La transacción en la nueva Ley de la jurisdicción contencioso-administrativa, Oñati, 2000, de quien tomo estas referencias).

${ }^{7}$ El nuevo Zeitgeist o espíritu del tiempo, la «mercantilización», que afecta también al Derecho administrativo, afecta más bien a cualquier fenómeno de nuestro tiempo. «Es en el siglo XIX cuando el teatro pasa a organizarse como mercado, confirmando y al mismo tiempo transformando su público» dice Piergiorgio Giacché (Teatro e Storia, 19, 1997). Otra cita de interés, en este mismo sentido, ahora desde la musicología, es aquella de Jacques ATTALI, para quien el músico, sucesivamente sacerdote, narrador, juglar, ministro, empresario, vedette, «ha terminado convirtiéndose en una mercancía que se compra, se vende, se consume, se gasta y se tira, bajo una pedagogía de consumo o show business» (Ensayo sobre la economía política de la música, Ruedo Ibérico, 1977).
\end{abstract}

Precisamente, si se ha caracterizado la realidad del presente como «posmodernidad» es debido al eclecticismo de la realidad actual, donde todo cabe y todo entra y donde todo se lía con lo otro, creándose una especie de espejismo de abundancia o engaño de realidad: el merchandising publicitario cuyo sentido está en crear un universo de consumo-espectáculo (puede verse Boletín de la Fundación Juan March, 290, 1999).

Por tanto, el problema no es el mercado. Mercado siempre hubo. El problema es que aquello que no se presenta como mercado lo sea en realidad, o termine siéndolo. Las actividades pierden sentido si se sitúan al margen de los negocios y esto llega a afectar a ámbitos propiamente intelectuales o científicos. Véase S. GonZÁlez-VARAS IbÁÑ̃zZ, La segunda realidad. Ensayo didáctico-satírico en busca de la realidad, sobre la fama y sobre las sensaciones (Editorial Comares, marzo 2002).

8 Así, en los convenios y en las transacciones lo característico es la primacía de la cultura del pacto y del do ut des. Esto es precisamente lo propio de las decisiones políticas. En el Derecho administrativo, en cambio, viene primando la idea de legalidad positiva, según la cual las decisiones tomadas por la Administración son aquéllas a las que necesariamente conduce la aplicación de la ley. Qué duda cabe que las disciplinas económica o mercantil y la política son aquellas disciplinas que predominan en el nuevo contexto social. Todo esto explicaría que se relacione la figura de la transacción con los pactos políticos y acuerdos parlamentarios, así como con las transferencias de servicios del Estado en las CCAA, los convenios de transferencia sectorial, los convenios de colaboración y acuerdos de cooperación (D. LOPERENA ROTA, La transacción en la nueva Ley de la jurisdicción contencioso-administrativa, Oñati, 2000, pp. 109 y 177 y ss.): «los Pactos Autonómicos y el Pacto local son claros ejemplos de controversias políticas de hondo calado que se resuelven por la vía del compromiso (...)».

Pero la propia política es en parte también pura economía. En la financiación de los partidos políticos, por ejemplo, irrumpe desde hace algún tiempo esta cultura de las transacciones en el sentido de 
De hecho, también la deformación o abuso de este tipo de figuras jurídicas (los arbitrajes) vendrá igualmente asociada a factores económicos, cuando concretamente los árbitros (y con ello el funcionamiento de los arbitrajes) terminan por ceder a la presión de los intereses económicos de alguna de las partes (como ilustra la experiencia de ciertos arbitrajes en Colombia y ciertos casos de corrupción que allí se habrían manifestado).

El espíritu de todas estas figuras mencionadas está en una libertad de negociar, algo que no casa bien del todo con el Derecho administrativo clásico.

Se sufre así una relajación de un criterio estricto de legalidad positiva administrativa y se experimenta la irrupción de formas administrativas de actuación negociada ${ }^{9}$ en contraposición a las formas y estilos jurídico-administrativos tradicionales de actuación.

Se habla, en este sentido ${ }^{10}$, por referencia a las transacciones, de la necesidad de una nueva cultura administrativa (la «cultura del pacto»), que llevaría a considerar válidas todas aquellas transacciones que no contravengan el ordenamiento jurídico o los intereses públicos ${ }^{11}$. Transacciones, convenios, arbitrajes, serían admitidos en esferas propias del giro o tráfico administrativo ${ }^{12}$. Asimismo, siempre que fuera posible, habría

\begin{abstract}
la posibilidad de realizar aportaciones a los partidos sin ocultar su vocación de influir en la toma de decisiones políticas una vez se proclama la candidatura que ha sido apoyada. Nuevamente, se pone de manifiesto, sobre el particular, el diferente tratamiento de esta cuestión en nuestra legislación española (donde las donaciones a los partidos se ven con especial escepticismo) y en la legislación de los países anglosajones (donde no sólo se admiten, sino que incluso se fomentan, dichas aportaciones, eso sí, a cambio de la debida transparencia en cuanto al conocimiento de las personas que realizan estas prácticas, insisto admisibles, con una finalidad de do ut des). Véase S. GonzÁLEZ-VARAS IBÁÑ̃z, La financiación de los partidos políticos, Editorial Dykinson, Madrid, 1995. Véase también un reciente artículo publicado en $D \ddot{O} V 18$ (2001), p. 750 (de G. RoELLECKE), cuyo expresivo título es precisamente: «¿Se puede comprar la política?».

9 Relaciono intencionadamente los términos «negocio» y actividad «negociada». Interesa destacar que el primer significado que el Diccionario de la Real Academia ofrece de «negociar» es el de «tratar y comerciar, comprando y vendiendo géneros, mercaderías o valores para aumentar el caudal», pero también «tratar asuntos públicos o privados procurando su mejor logro».
\end{abstract}

En este contexto, en el Derecho privado aparecen publicaciones donde se enseña a los abogados el manejo de las técnicas de negociación y mediación como «técnicas» de futuro y de mayor rentabilidad que el propio pleito (J. Malaret, Manual de negociación y mediación, Madrid, 2000).

${ }^{10}$ Las que siguen son básicamente las tesis de D. Loperena Rota, La transacción en la nueva Ley de la jurisdicción contencioso-administrativa, Oñati, 2000, in toto.

11 ¿Parece llegarse a un modelo de legalidad negativa? Se pueden celebrar transacciones a salvo de que «los acuerdos sean manifiestamente contrarios al ordenamiento jurídico» (D. Loperena RotA, La transacción..., p. 240).

12 «La transacción que habilitan estas leyes (LRJAP-PAC, LJCA) está vinculada al giro o tráfico administrativo sin discusión alguna» (p. 200). «La transacción se produce en el giro o tráfico admi- 
que procurar una conversión de dichas esferas en otras de carácter patrimonial, aplicándose entonces fácilmente las transacciones ${ }^{13}$. Lejos de su anormalidad, estaríamos ante figuras propias de Derecho administrativo (de naturaleza contractual ${ }^{14}$ ) y no ante un traslado de figuras de Derecho privado a un ámbito administrativo ${ }^{15}$. Eso sí, poco desarrolladas y que necesitan de una mayor aplicación. A la búsqueda de testimonios de transacciones en nuestro ordenamiento, llega a mantenerse un concepto lato de transacción que conduce a relacionar directamente la transacción con todos aquellos casos en los cuales las decisiones de la Administración cuentan con un asentimiento de los particulares o existe una conjunción de voluntades o incluso si, con anterioridad a la decisión administrativa, existe un requerimiento ${ }^{16}$. Sería entonces preciso actualmente, como primer paso encaminado en esta dirección, flexibilizar las actuales rigideces de tipo procedimental o material presentes en la legislación administrativa (esencialmente arts. 39 LGP y 40 LPE, que se estudian infra), abriendo en cambio «márgenes de negociabilidad». Como argumento de Derecho comparado se presenta, lógicamente, el modelo anglosajón, en el

nistrativo. Si la LJCA admite la transacción para terminar litigios que están sometidos a esta jurisdicción es porque, de acuerdo con su artículo 1 y concomitantes, se refiere a actos o disposiciones reguladas por el Derecho administrativo» (p. 215).

${ }^{13}$ Sobre esta cuestión, de especial significación, infra en el contexto de los arbitrajes.

14 «He señalado que se trata de un contrato administrativo» (p. 216). Sin embargo, no deja de ser algo paradójico, a mi juicio, que, siendo un contrato, termine afirmándose que «la regulación general de los contratos administrativos que hace la Ley es en gran medida inaplicable al contrato de transacción (...)». «De este modo, principios como el de libertad de concurrencia, o procedimientos de selección del contratista, carecen de posibilidad aplicativa» (p. 258).

15 «La transacción no es un hueco por donde entra el Derecho civil, sino que es una institución de Derecho común con unas peculiaridades propias en su aplicación por el Derecho administrativo, lo cual permite hablar de la transacción administrativa como una institución propia de aquella rama del Derecho con un régimen peculiar distinto del que pudiera deducirse del Código Civil y la Ley de Enjuiciamiento» (p. 200).

${ }^{16}$ Entre otros ejemplos, Loperena Rota considera en este contexto de la transacción casos como el del procedimiento de codecisión del artículo 251 del TCE, el requerimiento previo del artículo 62 de la LOTC (aportando tres ejemplos de transacciones en las resoluciones del TC: autos 124/1988, de 8 de noviembre; 485/89, de 3 de octubre y auto de 12 de febrero de 1991), incluso los deslindes administrativos (cuando el particular acepta la demarcación propuesta). También la regulación de la interpretación unilateral de los contratos de la Administración, el privilegio del ius variandi o la propia fase de resolución del contrato serían ejemplos de transacciones, en tanto en cuanto existe un expediente contradictorio.

Esta concepción tiene el mérito de informarnos que la transacción en cuanto tal no es tan ajena al Derecho administrativo como inicialmente podríamos pensar, aunque es discutible si no va más allá de los límites conceptuales lógicos de la transacción, entendiendo por tal toda decisión en torno a la cual existe una toma en consideración de voluntades diferentes de la instancia administrativa que dicta el acto o resolución. 
cual arraigan las transacciones y los negocios y el cual impulsaría la normalización de estas figuras dentro del Derecho administrativo español ${ }^{17}$.

En efecto, este fenómeno no es necesariamente, o en cuanto tal, algo negativo si uno considera las ventajas con las que se nos presentan estos nuevos productos que contrastan con la imagen de lentitud e inadaptación a los nuevos tiempos del Derecho administrativo. Salvando algún límite, la cultura del do ut des parece estar en la propia realidad de las cosas, pues éstas funcionan casi siempre mejor de este modo.

De ahí que se considere un logro la consagración de una «autonomía negocial» de la Administración, o de los «actos negociales sustitutivos» que «permiten una toma de decisión más acertada, con mejor conocimiento de causa, al conocer los puntos de vista de los propios interesados, lo que viene a favorecer la ejecución de la decisión misma» ${ }^{18}$.

O que se diga, igualmente, que «el empleo de técnicas de negociación con agentes privados ha sido una cuestión cotidiana de las Administraciones públicas contemporáneas, pues en verdad resulta impensable abordar la ejecución de contratos administrativos o las relaciones laborales, sin que las partes se encuentren transitando por caminos de la negociación, sobre las modificaciones contractuales, los modos de ejecutar las prestaciones, la sustitución de obligaciones o la liquidación de contratos» ${ }^{19}$.

De ahí también que se apunte (por A. PETERS) que «la tesis clásica de la actuación del Estado al margen de criterios económicos («Fremdheit der fiskalischen Interessen des Staaten») aparece en el mundo actual como una tesis desfasada, considerando los modelos imperantes de carácter predominantemente económico» ${ }^{20}$.

17 A esto lo denomina D. Loperena Rota, con evidente acierto y realismo, «la superación del dogmatismo paralizante», ya que «en el mundo anglosajón la preocupación se orienta fundamentalmente a la búsqueda de soluciones prácticas. Los conceptos no son tan importantes...» (La transacción en la nueva Ley de la jurisdicción contencioso-administrativa, Oñati, 2000 in toto).

18 F. Delgado Piqueras, en Jornadas de Estudio sobre la reforma de la Ley 30/1992, Madrid, 1997; del mismo autor, La terminación convencional del procedimiento expropiatorio, Pamplona, 1995.

19 J. C. Morón Urbina, «La solución alternativa de controversias en sede administrativa. De la imposición unilateral de la autoridad a la conciliación de intereses en asuntos administrativos», CEPSCON, Centro Peruano de Solución de Conflictos, @dministración, ciberrevista de Derecho administrativo n. ${ }^{\circ}$ 12, octubre-diciembre 1999, www.derecho.unican.es/administracion; véase sobre estas cuestiones también A. BustamANTE BELAÚNDE, «Justicia alternativa», Instituto de economía de Libre mercado, 1993, p. 116, quien aboga por desjudicializar de forma inmediata los procedimientos no contenciosos.

${ }^{20}$ A. Peters, «Die Ausfüllung von Spielräumen der Verwaltung durch Wirtschaftlichkeitserwägungen», $D \ddot{O V}, 18,2001$, p. 750 . 
En conclusión, junto a otras posibles interpretaciones, las actividades negociadas pueden ser vistas junto a todos aquellos fenómenos que actualmente informan de la progresiva mercantilización de ámbitos administrativos (tales como la creciente aplicación del Derecho de la competencia en ámbitos donde tradicionalmente imperaban las regulaciones de Derecho administrativo, el desarrollo de una idea de colaboración empresarial en el ejercicio de funciones públicas, o el triunfo de los fenómenos de privatización, liberalización y desregulación sobre los servicios públi$\cos )^{21}$.

\section{LA POSIBILIDAD DE CONVENIR CON LOS PARTICULARES}

\section{A) Manifestaciones principales de los acuerdos procedimentales}

Los convenios no son un invento de la reciente legislación administrativa (por ejemplo, la LEF, en su art. 24, prevé los convenios expropiatorios para la determinación del justiprecio 22 y tampoco los convenios urbanísticos son desconocidos para el Derecho urbanístico clásico), aunque aquéllos empiezan a cobrar mayor auge en los últimos tiempos.

El punto de referencia principal en la actualidad sería la terminación convencional (o finalización de los procedimientos administrativos mediante acuerdo) prevista en los artículos 88, 109.e) de la LRJAP-PAC y Disposición Adicional cuarta de la Ley de Contratos de las Administraciones Públicas; SAN de 13 de marzo de 1995 AA, 34, 1998 § $6622^{23}$ ).

${ }^{21}$ Sobre todos ellos S. GonZÁlez-VARAS IBÁÑ̃z, Los mercados de interés general: de telecomunicaciones y postales, energéticos y de transportes, Editorial Comares (Granada), septiembre 2001; igualmente F. GarRIDo Falla, «¿Réquiem por el servicio público»?, Cuenta y Razón, junio-julio 2000 , p. 7, y C. PieLow, Strukturen öffentlicher Versorgung, Tubinga, 2001. Y por supuesto imprescindible la consulta del Manual de gestión de servicios públicos locales, Editorial Aranzadi, de F. SOSA WAGNer.

22 Véase E. García de Enterría/T. R. Fernández, Curso de Derecho administrativo (II), Madrid, 1993, pp. 291 y ss.; J. A. García-Trevijano Fos, Los convenios expropiatorios, Madrid, 1979; N. GonzÁlez-Cú́llar Serrano, Los procedimientos tributarios: su terminación transaccional, Madrid, 1998; J. M. Chamorro GonZÁLeZ, «Terminación convencional y silencio administrativo», $A A$, 41, 2001, p. 1341.

${ }^{23}$ En dicho artículo 88.1 se prevén (por primera vez expresamente en el Derecho español) los acuerdos procedimentales en general, en el contexto de la terminación o finalización del procedimiento (arts. 87 y ss. de la LRJAP-PAC). El artículo 88.1 de la LRJAP-PAC regula la «terminación convencional»: «las Administraciones Públicas podrán celebrar acuerdos, pactos, convenios o contratos con personas tanto de Derecho público como privado, siempre que no sean contrarios al ordenamiento jurídico ni versen sobre materias no susceptibles de transacción y tengan por objeto satisfacer el interés público que tienen encomendado, con el alcance, efectos y régimen jurídico especí- 


\section{Además, pueden citarse otras manifestaciones de la terminación con- vencional:}

1. Posibilidad de terminación convencional en caso de acuerdos indemnizatorios, es decir, acuerdos en los que se determina la cuantía de la indemnización (arts. 2.2 y 3, 11.2 del Real Decreto 429/1993, de 26 de marzo).

2. Posibilidad de terminación convencional para la determinación de la cantidad en concepto de reparación de daños en favor de la Administración (art. 22.2 del Real Decreto 1398/1993, de 4 de agosto, donde se admite la terminación convencional en estos casos, en los que, además de la imposición de una sanción, es preciso reclamar de forma igualmente ejecutoria la reparación del daño causado en un procedimiento complementario al de la sanción).

3. Posibilidad de la terminación convencional en los casos de procedimientos complementarios de determinación de las cantidades que han de devolverse por un alto cargo en aplicación del Real Decreto 1410/1995, de 4 de agosto, por el que se regulan los Registros de Actividades y de Bienes y Derechos Patrimoniales de los Altos Cargos (art. 24), en desarrollo de la Ley 12/1995, de 11 de mayo, de incompatibilidades de los altos cargos de la Administración General del Estado.

4. Posibilidad de terminación convencional del procedimiento para la concesión de subvenciones públicas (art. 7.1 del Real Decreto 225/1993, de 17 de diciembre).

5. Posibilidad de terminación convencional del procedimiento de otorgamiento, modificación y extinción de autorizaciones (art. 5 del RD 1778/1994, de 5 de agosto).

6. Posibilidad de terminación convencional del procedimiento para otorgar la autorización administrativa, en aplicación de la Ley 5/1995, de 23 de marzo, de enajenación de participaciones públicas en determinadas empresas ${ }^{24}$.

fico que en cada caso prevea la disposición que lo regule, pudiendo tales actos tener la consideración de finalizadores de los procedimientos administrativos o insertarse en los mismos con carácter previo, vinculante o no, a la resolución que les ponga fin» (véanse el art. 104 y DA 4. ${ }^{a}$ de la LCAP y art. 111 TRL).

En el artículo 88.2 se recoge el contenido mínimo de los citados instrumentos. En el 88.3 se afirma que requerirán la aprobación expresa del Consejo de Ministros los acuerdos que versen sobre competencia directa de dicho órgano (véase art. 5 Ley del Gobierno). En el artículo 88.4 se sienta que los acuerdos que se suscriban no supondrán alteración de las competencias atribuidas a los órganos administrativos (...).

Un problema importante, sobre el cual no existe solución unánime en la doctrina, es el de si el artículo 88 citado tiene directa aplicación o si precisa de normas de desarrollo; véase en detalle R. O. Bustillo Bolado, Convenios y contratos administrativos: transacción, arbitraje y terminación convencional del procedimiento, Pamplona, 2001, pp. 264 y ss.

${ }^{24}$ Sobre esta Ley 5/1995, de 23 de marzo, de enajenación de participaciones públicas en determinadas empresas puede verse S. GonZÁlez-VARAs IBÁÑEZ, Los mercados de interés general: de telecomunicaciones y postales, energéticos y de transportes, Editorial Comares (Granada), septiembre 2001. 
7. Posibilidad de terminación convencional en el procedimiento para el control de las concentraciones económicas (art. 15 ter del RD-Ley 6/1999, de 16 de abril, de Medidas Urgentes de Liberalización e Incremento de la Competencia) ${ }^{25}$.

8. Posibilidad de celebrar acuerdos ambientales con repercusión sobre la autorización de actividades contaminantes o agresivas para el medio ambiente en el marco de la Ley catalana 3/1998, de 27 de febrero ${ }^{26}$.

\section{B) Selección de un ejemplo: los convenios urbanísticos; la influencia de los intereses privados en materia urbanística (la «privatización» del urbanismo)}

Los convenios urbanísticos, institución en auge, representan ejemplarmente la idea de colaboración de los particulares en el ejercicio de la función pública urbanística.

No obstante su actualidad, al urbanismo histórico no han sido ajenos los convenios urbanísticos. En el siglo XIX, los convenios aparecen junto a las distintas técnicas o acciones más características del momento. En el contexto de las alineaciones, los convenios se celebran con el fin de evitar el procedimiento expropiatorio o de agilizarlo una vez que éste se ha puesto en marcha; pueden, por tanto, asociarse aquéllos a la necesidad de facilitar la adquisición de suelo por parte de los poderes públicos. Asimismo, cuando la Administración impulsa los característicos procesos de ensanche y reforma interior de las ciudades, surgen convenios como medio para fomentar la colaboración del particular en la realización de las obras de urbanización $y$, por tanto, como cauce de colaboración en el ejercicio de una función pública, la urbanística. En definitiva, desde siempre se han puesto de manifiesto ciertas limitaciones con las que se enfrenta la acción pública urbanística (en este contexto de cara a la realización de las obras necesarias) y, por tanto, la necesidad de buscar la colaboración de los particulares. También se deja espacio a la colaboración o iniciativa privada en el contexto de la implantación de las disposiciones higiénicas y sanitarias (mediante exenciones tributarias y subvenciones en favor de empresas colaboradoras; art. 12 de la Ley de Casas Baratas de 1911).

\footnotetext{
25 Para otros supuestos de terminación convencional previstos en la legislación autonómica, A. DE Palma del Teso, Los acuerdos procedimentales en el Derecho administrativo, Valencia, 2000, pp. 103. Y para la actividad convencional en el ámbito tributario, pp. 178 y ss.; puede verse también F. Velasco Caballero, Las cláusulas accesorias de los actos administrativos, Madrid, 1996.

26 Puede verse D. SANZ PÉREZ, «Los acuerdos ambientales como mecanismo de sustitución o complemento del control preventivo unilateral de las actividades potencialmente contaminantes: las previsiones de la Ley 3/1998», Revista interdisciplinar de gestión ambiental, 34, 2001, pp. 11 y ss.
} 
La LS 1956, a pesar de pretender la unilateralidad de decisiones, no pudo renunciar a la actuación de los particulares mediante convenios o formas convenidas de colaboración con los particulares en el ejercicio de la función pública urbanística (arts. 137 a 141, donde se regula la colaboración de los particulares en labores de ejecución, previéndose el concesionario de obra urbanizadora seleccionado por licitación pública; art. 117, donde se prevén convenios para costear las obras de urbanización de los propietarios).

Pero es precisamente por reacción frente a la LS 1956 como en realidad se introduce en sentido moderno, por el TRLS 1976, el llamado urbanismo concertado (con el antecedente del Decreto 2432/1972, de 18 de agosto). En suma, facilitando la actuación de los particulares mediante convenios, se prevé la posibilidad de que las Entidades locales, de oficio o a instancia de parte, convoquen concursos para la formulación y ejecución de los Programas de Actuación Urbanística (por tanto, en suelo urbanizable no programado), con la consiguiente adjudicación a un concursante que deberá formular el correspondiente Programa de actuación de acuerdo con el avance de planeamiento aprobado. No obstante, dichas Entidades podían ejecutar directamente los PAU o prescindir de la apertura del concurso (arts. 146 y ss. del TRLS 1976).

Por su parte, la LRSV 1998 considera que «en los supuestos de actuación pública, la Administración actuante promoverá, en el marco de la legislación urbanística, la participación de la iniciativa privada», y en su filosofía la LRSV de 1998 no es distante del TRLS 1976 (ni tampoco del espíritu del desarrollismo económico de los tiempos del TRLS 1976) ${ }^{27}$.

\footnotetext{
${ }^{27}$ Por lo que se refiere al TRLS 1992, no parte éste de la ratio del urbanismo concertado, sino más bien de la idea del dirigismo de los poderes públicos (véase el art. 19). No obstante, en primer término, el TRLS 1992 confirma que las Entidades locales puedan convocar concursos para la formulación y ejecución de los Programas de Actuación Urbanística (arts. 177 a 184). Contempla asimismo otros casos o ejemplos relacionables de forma más o menos directa con formas de actuación convenida entre particulares y Administración. Éste es el caso de los convenios que puede celebrar la Administración con los particulares para satisfacer el justiprecio mediante la adjudicación de terrenos situados dentro o fuera del área de reparto donde se encuentran los expropiados (art. 217), o para llevar a cabo una expropiación (art. 213) o para la constitución de servidumbres cuando «para la ejecución de un Plan no fuere menester la expropiación del dominio» (art. 211), o para fijar los compromisos que se hubieren de contraer entre el urbanizador y el Ayuntamiento en los casos de planes de iniciativa particular [art. 105.2.d)]. Se sitúan en esta línea los convenios mediante los cuales se permite que el pago de los gastos de urbanización, que han de asumir los propietarios, se haga mediante terrenos edificables o se haga de forma aplazada (arts. 155.2 y 163.3, respectivamente). También puede encajar en este contexto el supuesto contemplado en el artículo 151.4, donde se faculta a la Administración a transmitir los excesos de aprovechamiento siempre que el uso de los terrenos en la unidad de ejecución no sea adecuado a los fines del Patrimonio Municipal del suelo. En este contexto, el artículo 282.2 permite las cesiones de Patrimonio municipal de suelo, donde nue-
} 
Pero la actuación de los particulares mediante convenios o formas convenidas de colaboración desborda los márgenes de cualquier previsión legal (en general, véanse los arts. 88 de la LRJAP-PAC 30/1992, 111 TRRL 1986, 4 LCAP, art. 77 LJCA). Estamos ante uno de esos fenómenos que impulsan nuevas necesidades y tendencias sociales asociadas tanto a una ágil y eficaz gestión administrativa como a la conveniencia de abrir mayores cauces de participación de los particulares en el ejercicio de funciones públicas, como es el caso de la urbanística.

Se generan así convenios urbanísticos atípicos dirigidos a la modificación del planeamiento urbanístico, torpedeando el contenido y funcionalidad de los planes generales. Mediante este tipo de convenios, el Ayuntamiento se compromete a clasificar o calificar los terrenos atribuyéndoles determinados usos e intensidades y el propietario a compensar los beneficios adquiridos, incrementando las cesiones gratuitas al Ayuntamiento más allá de las cesiones previstas en el ordenamiento jurídico. Pero los convenios también podrán celebrarse con fines recaudatorios o, lo que es más problemático, eludiendo la aplicación de medios coercitivos y sancionadores, a los efectos de conseguir la legalización de ciertas acciones urbanísticas. Es «problemático» cuando de esta forma se eluda la imposición de una sanción que deba aplicarse.

La colaboración mediante los convenios se inspira en parte en la idea del do ut des. Ambas partes convienen la satisfacción de sus intereses recíprocos, para mejor realización de los fines públicos en caso de la Administración. Y es obvio que este planteamiento lleva consigo la necesidad de aplicar límites jurídicos. Pero antes de mencionar los límites y garantías es preciso insistir en la idea anterior, esencial a los pactos o convenios y que en lo urbanístico lleva a conceder a la Administración la posibilidad de aprovechar los márgenes de apreciación o discrecionalidad que le otorga la legalidad administrativa a la hora de realizar el planeamiento urbanístico; siendo varias las opciones posibles, podrá buscarse un punto de encuentro con los intereses de los particulares y sacar provecho de este tipo de circunstancias para la mejor realización de los fines públicos que, a la postre, es lo que interesa. El particular, movido por su propio interés, colabora en definitiva en la mejor realización de los intereses públicos. La posición jurídica del particular que pacta con la Administración no es la de un concesionario, sino la de un «colaborador» en el ejercicio de funciones públicas.

vamente puede ser encajado el convenio (con las limitaciones, no obstante, que prevén los preceptos siguientes).

En la práctica, las cesiones de terrenos vía convenio son uno de los objetos principales de los convenios (por todas, STS de 18 de junio de 1991, Ar. 5186). 
Es obvio, como decíamos, que este tipo de planteamientos acentúe la necesidad de transparencia y de publicidad en la celebración de convenios. El problema jurídico de los convenios es, en realidad, el problema de sus límites y controles jurídicos.

Los convenios «atípicos» son cada vez más «típicos», desde el momento en que la legislación urbanística autonómica, superando ciertos reparos de la jurisprudencia, reconoce y matiza el empleo de los convenios urbanísticos (disposición adicional cuarta de la Ley valencia 4/1992, de 5 de junio, de Suelo no urbanizable).

El reconocimiento de los convenios pasa necesariamente por establecer límites jurídicos, insistiendo en su transparencia y su publicidad. Esto es en definitiva lo que hace dicha legislación autonómica nada más reconocer los convenios urbanísticos, tanto respecto de los convenios para la ejecución del planeamiento [art. 74.3.a) de la Ley madrileña 9/1995, de 28 de marzo, de Ordenación del Territorio y Urbanismo], como de los convenios que se suscriban con motivo de la formulación y aprobación de los planes (disposición adicional cuarta de la Ley valencia 4/1992, de 5 de junio, de Suelo no urbanizable, apartado cuarto) o con el objeto de que la Administración tome la iniciativa y tramitación de los pertinentes procedimientos para la modificación del planeamiento (art. 140.5.2 de la Ley 10/1994, de Navarra; arts. 83 y 84 de la Ley 5/1999 de Aragón).

Otros límites que es preciso aunque sólo sea recordar se refieren a la imposibilidad de contravenir el ordenamiento jurídico y a la indisponibilidad de las potestades públicas (art. 94.2 de la Ley 5/1999, de 5 de abril, de Castilla y León). Dicha indisponibilidad es un criterio o límite sobre el que incide de forma especial la jurisprudencia. Así, la STS de 15 de abril de 1992, Ar. 4051, afirma que «no resulta posible una disposición de la potestad de planeamiento por vía contractual (...)». «Nunca podría aquél (el convenio) limitar el contenido de las potestades autonómicas» (STS de 13 de febrero de 1992, Ar. 2828). «Aquella potestad ha de actuarse para lograr la mejor ordenación posible, sin perjuicio de las consecuencias jurídicas que ya en otro terreno pueda desencadenar el apartamiento de convenios anteriores» (STS de 13 de julio de 1990, Ar. 6034).

De entre la numerosa jurisprudencia existente, una sentencia ilustrativa sobre el correcto funcionamiento de los convenios es la STS de 15 de febrero de 1994, Ar. 1448, en tanto en cuanto primero establece ciertos límites y reservas y, segundo, admite la celebración de los convenios aportando datos de interés sobre su sentido y alcance práctico. Por una parte, 
«el convenio viene a ser un instrumento facilitador de la actuación urbanística que en modo alguno puede implicar derogación (ni en beneficio de la Administración ni en favor de los particulares) de las reglamentaciones de carácter imperativo, ni puede condicionar el ejercicio de las potestades urbanísticas, por ser el urbanismo una auténtica función pública indisponible e irrenunciable».

Entendido así, añade dicha STS de 15 de febrero de 1994, Ar. 1448, no existen mayores problemas para admitir un convenio que venga a plasmar en la realidad lo establecido en el planeamiento. Concretamente en el presente supuesto, el convenio plasma «la expectativa de aprovechamiento que la parte actora tenía, por reconocérselo así las Normas subsidiarias (...) favoreciendo y facilitando la gestión de la urbanización (...), por localizar y materializar parte del proceso ejecucional a efectos urbanísticos mediante la cesión de los terrenos de cesión obligatoria y gratuita a que estaba obligada la parte actora al amparo de lo dispuesto en los artículos 83.3.1, 120 y 124.1 de la Ley del Suelo, concretando igualmente el volumen de edificabilidad de la parte actora de los terrenos de su propiedad (...)».

En esta línea de sacar partido, en buen sentido, a la figura del convenio se sitúa también la STS de 25 de marzo de 1992, Ar. 3387. El convenio viene a evitar, en este caso, la indemnización prevista en los artículos 41 y ss. de la LRSV, lo que evidentemente contribuye a realizar o favorecer los intereses públicos siempre que no se pongan en riesgo otro tipo de valores jurídicos superiores: «al tratarse pues de un Plan Parcial en curso de ejecución y sin posibilidad de consumación, el referido Convenio urbanístico ofrecía como la única posibilidad viable para eludir las consecuencias indemnizatorias a que se refiere el artículo 87.2 de la Ley del Suelo, que, en otro caso, hubieran devenido inevitables.»

Pero el convenio no sólo debe respetar las leyes, sino también los planes urbanísticos: «el convenio urbanístico no tiene, en general, y por sí solo valor normativo reglamentario autónomo, ni puede prevalecer en definitiva contra las determinaciones del Plan que ulteriormente se apruebe» (STS de 29 de noviembre de 1993, Ar. 9062; igualmente, STS de 16 de febrero de 1993, Ar. 1204; STS de 30 de octubre de 1997, Ar. 7638).

No obstante, como esta misma sentencia (STS de 29 de noviembre de 1993, Ar. 9062) reconoce, «el convenio deja de ser convenio si es asumido válidamente por el Plan, pues a partir de entonces sus estipulaciones 
cuentan como determinaciones de éste» (véase también la STS de 6 de noviembre de 1997, Ar. 8003).

El convenio, como forma de actuación administrativa, no podrá llevar a una huida del Derecho administrativo, lo que ocurre cuando se utiliza un convenio en lugar de otra forma de actuación, que es la que procede conforme al objeto que se pretende. Es el caso de la STS de 18 de octubre de 1990, Ar. 8145, que sienta la «nulidad radical» de un convenio de permuta de bienes, «por cuanto el mismo, pese a tratarse de una permuta de bienes de las Corporaciones locales, fue celebrado sin darse cumplimiento a lo prescrito en el artículo 98.2 del Reglamento de Bienes de las Corporaciones locales, precepto este último que exige para la procedencia de la permuta la previa tramitación de un expediente que acredite su necesidad, así como la equivalencia de valores». La nulidad radical se presenta «al haber sido adoptado prescindiendo total y absolutamente del procedimiento legalmente establecido» (otros ejemplos en la STS de 15 de febrero de 1999, Ar. 1705).

Pero será necesario estar al caso concreto. A veces un convenio será una simple forma de regular o definir el régimen de obligaciones de los propietarios, definido en el ordenamiento jurídico. Una licencia condicionada a la realización de ciertas cesiones no es tanto un convenio como una obligación legal (STS de 25 de enero de 1999, Ar. 178).

Por su parte, alguna legislación autonómica urbanística afirma también el principio de concurrencia. En este sentido, el artículo 74.2 de la citada Ley de Madrid afirma que la negociación, formalización y el cumplimiento de los convenios urbanísticos se rigen con carácter general por el principio de concurrencia. Esta mención se explica ante el interés especial, que antes se explicaba, de poner límites jurídicos a la celebración de los convenios. No obstante la bondad que encierra esta regla, lo cierto es que por pura lógica no siempre será factible la concurrencia, sin que ello suponga un problema jurídico (numerosos convenios son susceptibles de celebración con un único sujeto o grupo de sujetos: convenios expropiatorios, o de pactos de gastos de urbanización, etc.). De hecho, alguna legislación autonómica más reciente afirma, con acierto, que los convenios se rigen por «los principios de transparencia, publicidad y, cuando proce$d a$, concurrencia» (art. 11.2 in fine de la Ley 2/1998 de Castilla-La Mancha).

Quiere decirse de esta forma que, si bien en los contratos administrativos típicos la observancia del principio de concurrencia es esencial al ca- 
rácter público de dichos contratos, el quid del sistema jurídico-público de garantías en el ámbito de los convenios está más bien en la transparencia y la publicidad como forma de compensar la libertad de pactos, tan visible en la celebración de los convenios urbanísticos.

\section{TRANSACCIONES}

\section{A) Transacción extraprocesal}

A diferencia de los convenios, los cuales sustituyen o predeterminan un procedimiento administrativo, las transacciones sustituyen un proceso judicial (al igual, en esto, que los arbitrajes).

La transacción ha de entenderse, pues, como un medio de resolución extrajudicial de conflictos (así se caracteriza aquélla en el propio CC: art. 1.809; para la delimitación entre transacciones y convenios puede también consultarse la STS de 29 de abril de 1988, RJ 3157).

En este sentido, cuando se realiza un convenio no se zanja una controversia judicial, ya que más bien se está acordando un régimen de derechos y obligaciones que servirá de pauta para el ejercicio de las potestades administrativas, anticipando el resultado del procedimiento administrativo. Con la transacción, más bien, se zanjan las actuaciones y se evita un proceso judicial ${ }^{28}$.

Por otra parte, si bien el presupuesto normativo general y directo del convenio puede encontrarse en el artículo 88 de la LRJAP-PAC, el de la transacción se encuentra en principio en el CC, además de que la transacción, y no la terminación convencional, precisa obligatoriamente de dictamen del Consejo de Estado o de órgano autonómico equivalente. En el segundo caso precisan un Decreto (arts. 39 LGP y 40 LPE), en el primero basta una autorización del Consejo de Ministros u órgano ejecutivo autonómico.

El presupuesto de la transacción es que exista una controversia. Entonces, su sentido será el de evitar el pleito, al que conduciría dicha contro-

\footnotetext{
${ }^{28}$ Puede verse, sobre la transacción, J. M. BoQUera OLIVER, «Administración Pública y transacción», REVL, XXIV, 1965, n. ${ }^{\circ}$ 141, pp. 321 y ss.; M. ClaVero ArÉVALO, «Posibilidades de transacción con la Administración local», REVL, 74, 1954, pp. 161 y ss.; J. GonZÁLeZ PéReZ, «La transacción en el Proyecto de Ley de la jurisdicción contencioso-administrativa», $R A P, 145$, pp. 7 y ss.; M. SÁNCHEZ MoRón, «El régimen de los actos y los recursos administrativos en la LRJAP-PAC», en VV.AA., Ciudadanos y reforma administrativa, Madrid, 1995, pp. 249 y ss.
} 
versia, o ponerlo fin si éste hubiera comenzado ${ }^{29}$. Para ello, ambas partes pueden transigir mediante recíprocas concesiones. Su sentido práctico está, pues, en hacer posible que la Administración llegue a un acuerdo para zanjar las controversias e incertidumbres existentes.

Con la evitación de un pleito se evita al mismo tiempo la incertidumbre del resultado en la resolución judicial de la controversia. De ahí que el Consejo de Estado haya podido condicionar la posibilidad de las transacciones a aquellos casos en que pueda suponerse probabilidad de éxito del recurso planteado (dictamen $n^{\circ}$ 36277, de 14 de mayo). Dichos dictámenes informan además que por la materia las transacciones administrativas tienen lugar fundamentalmente respecto de cuestiones patrimoniales (así, por ejemplo, indemnizatorias en casos de liquidaciones de concesiones administrativas ${ }^{30}$ ) y de Derecho privado de la Administración (especialmente explotación de bienes patrimoniales).

No obstante, de los artículos 88.1 de la LRJAP-PAC y 77.1 de la LJCA se infiere que la transacción ha de contar con ciertos límites. En principio, parece difícil, si no imposible, imaginar la posibilidad de una transacción en los casos en que la Administración ejercite una potestad reglada (en este contexto habría que mencionar el principio de la indisponibilidad de las potestades administrativas). Los límites se referirían, por tanto, a aquellos casos en que se ejercite una potestad discrecional (y serían entonces de obligado acatamiento principios tales como los de motivación, plena adecuación con los intereses presentes en la relación jurídica objeto de transacción, ausencia de desviación de poder, etc.).

Por otra parte, su ámbito propio parece ser, conforme a su propia naturaleza, el de las relaciones de tipo patrimonial ${ }^{31}$.

\footnotetext{
29 Ilustra, por ejemplo, la noticia (tomada del periódico El País de noviembre de 2001): «el Gobierno rebaja de nuevo la tasa de los móviles para evitar el conflicto judicial»: «el pacto se certificó mediante una enmienda a los Presupuestos de 2002 presentada ayer con carácter de urgencia por el Grupo Popular en el Senado)», pero «lo cierto es que el Gobierno ha adoptado esta decisión tras arduas negociaciones...». «Los operadores habían recurrido la tasa ante el Tribunal Económico-administrativo Central y, tras ser desestimado en esta vía administrativa, anunciaron que llevarían el asunto ante la Audiencia Nacional. Sin embargo, los operadores se han comprometido a no seguir la vía judicial».

30 Dictámenes de 11 de marzo de 1976 (n. $\left.{ }^{\circ} 40027\right), 20$ de mayo de 1977 (n. $\left.{ }^{\circ} 40626\right)$, de 2 de noviembre de 1967 (n. $\left.{ }^{\circ} 35577\right), 29$ de abril de 1982 (n. $\left.{ }^{\circ} 44122\right)$, etc.

${ }^{31}$ Un ejemplo puede ser la STS de 25 de marzo de 1992, Ar. 3387, es decir, una transacción mediante la cual los interesados admiten una reubicación de los primitivos aprovechamientos urbanísticos a cambio de ceder en sus pretensiones indemnizatorias contra la revisión de un plan que realizaba una recalificación del suelo declarando no urbanizable el suelo donde dichos interesados habían realizado cuantiosas inversiones. Otro ejemplo es el recogido en la Ley 6/1996, de 8 de julio, que autoriza al Gobierno una transacción con el Canal de Isabel II para la cancelación de una deuda. Véase R. O. Bustillo Bolado, Convenios y contratos administrativos: transacción, arbitraje y ter-
} 
Así pues, en todo caso, la legalidad administrativa ha de respetarse. La propia definición del Diccionario de la Real Academia sobre el término «transigir» es a mi juicio bastante explícita de la problemática que encierra esta figura jurídica de la transacción. «Transigir» es «consentir en parte lo que no se cree justo, razonable o verdadero a fin de acabar con una diferencia». ¿Y es posible consentir en el ejercicio de las potestades públicas? Por otra parte, el renglón que acaba de escribirse «a fin de acabar con una diferencia» es también importante, ya que nos indica el beneficio que se consigue, es decir, la terminación de una contienda.

No pueden, en efecto, olvidarse los riesgos que presentan este tipo de figuras como la conciliación o transacción. La difusión de las soluciones negociales sin regulación apropiada puede llegar a poner en riesgo el resguardo del interés público (W. BROHM ${ }^{32}$ ).

Especialmente atentos habremos de estar a la posibilidad de que, mediante su empleo, se encubran fraudes de ley administrativa ${ }^{33} \mathrm{o}$ la satisfacción de intereses personales por encima de los propios intereses públicos.

Así pues, ni la transacción debe negarse alegando falsos límites (tales como desigualdad de los sujetos en las relaciones jurídicas administrativas, imposibilidad de comprometer al erario vía conciliación, la presunción de legalidad de los actos administrativos ${ }^{34}$ ), ni tampoco afirmarse olvidando ciertos límites esenciales frente a su aplicación en el caso concreto, es decir, límites reales aunque no insuperables (principio de legalidad de las actuaciones públicas y por tanto solución conforme a Derecho, autonomía de voluntad en sentido de libertad de las partes para conciliarse, interés público o finalidad pública del acuerdo conciliatorio).

Pero lejos de una regulación precisa sobre el particular, en el Derecho administrativo español no existen más que normas de tipo procedimental, respecto de la transacción, esencialmente el artículo 39.1 de la LGP ${ }^{35}$ o

\footnotetext{
minación convencional del procedimiento, Pamplona, 2001, pp. 210 y ss.; esta obra, aunque no ignora que el ámbito propio de la transacción es el «patrimonial» 0 «hacendístico», admite la transacción en otros casos no patrimoniales, a pesar de que deja esta afirmación sin concretar. Un caso que se analiza detalladamente es el de la transacción en los procedimientos concursales.

32 W. BRонм, «Sobre la aceleración de los procedimientos, ¿una mayor disciplina o una consensuación de la acción administrativa?», Documentación Administrativa, 235-236, 1993, pp. 387 y ss.

${ }^{33}$ En esta línea, un dictamen del Consejo de Estado, de 30 de mayo de 1968 (n. $\left.{ }^{\circ} 35965\right)$, reacciona contra una transacción que pretendía justificar una enajenación soslayando las garantías legales para la enajenación de bienes municipales y entre ellas la subasta pública.

34 J. C. Morón Urbina, cit., pp. 16 y ss.

${ }^{35}$ Según el citado artículo 39.1 de la LGP, «no se podrá transigir judicial ni extrajudicialmente sobre los derechos de la Hacienda Pública, ni someter a arbitraje las contiendas que se susciten res-
} 
40 de la LPE ${ }^{36}$ y el artículo 77 de la LJCA ${ }^{37}$, a diferencia, por ejemplo, del ordenamiento alemán, donde se ha conseguido una regulación sustantiva en la LPA (art. 55, junto al 106 de la LJCA), desarrollada y matizada jurisprudencialmente ${ }^{38}$ conforme al frecuente uso que se hace en la práctica de las transacciones. También en el ámbito autonómico y local las referencias son esencialmente de igual carácter procedimental ${ }^{39}$. En el Derecho comunitario europeo está presente, en cambio, una voluntad más decidida por la instauración de sistemas u órganos de transacción o acuerdo, tanto mediante comisiones parlamentarias como a través de la actuación del Defensor del pueblo. En este sentido, también en el Derecho español esta institución del Defensor del pueblo (en el ámbito estatal y en el autonómico) permite llegar a la concertación de transacciones y acuerdos entre Administración y particulares.

Además, se regula un trámite de conciliación en los artículos 68 y ss. de la Ley 48/1998, de 30 de diciembre, sobre Procedimientos de contratación en los sectores del agua, la energía, los transportes y las telecomunicaciones, por la que se incorporan al ordenamiento jurídico español las directivas 93/38/CE y 92/13/CEE.

pecto de los mismos, sino mediante Real Decreto del Consejo de Ministros, previa audiencia del de Estado en Pleno».

36 Respecto de los bienes o derechos del patrimonio del Estado, dicho artículo exige Decreto del Consejo de Ministros, a propuesta del de Hacienda, con audiencia del de Estado en Pleno.

37 Asimismo, en el artículo 117.3.1 del RD-Legislativo 2/2000, de 16 de junio, por el que se aprueba el TR de la LCAP, se reconoce la posibilidad de transigir previa autorización del Consejo de Ministros «en los contratos con empresas extranjeras (...)».

38 En esta línea habría que considerar además el artículo 38.1 del Convenio europeo para la protección de los derechos humanos y las libertades fundamentales, donde se afirma que si el tribunal declara admisible una demanda procederá al examen contradictorio del caso y procurará un acuerdo amistoso (...). Respecto del Derecho alemán es preciso tener en cuenta que en el proceso contencioso-administrativo alemán rigen los principios de investigación de oficio y de aclaración judicial en favor de las partes, con un importante y activo papel del juez, que permite a éste forzar la conciliación en el proceso. Sobre la conciliación puede verse S. GonZÁLEZ-VARAs IBÁÑ̃z, La jurisdicción contencioso-administrativa en Alemania, Madrid, 1993, p. 417. Según el significativo artículo 55 de la LPA, «cuando la Administración lo estime conveniente podrá celebrar contratos de Derecho público de los previstos en el artículo 54, por los que resuelva, mediante concesiones recíprocas, una incertidumbre que resulte de una valoración prudente de las circunstancias de hecho o de la situación jurídica» (puede verse M. Fromont, «L'example allemand», $A J D A$, 1997, pp. 59 y ss.).

39 Pueden verse los artículos 23.1.a) y 28.1.c) del TRRL/1986 (atribuyendo al Pleno la competencia para transigir). En el caso autonómico, la legislación, muy numerosa, sigue la ratio de la legislación estatal, debiéndose consultar la legislación pública de patrimonio o de hacienda o régimen presupuestario. 


\section{B) Transacción judicial o conciliación}

La introducción de la conciliación en el proceso administrativo puede verse también en sintonía con la paulatina evolución favorable que en el Derecho administrativo se advierte en relación con los fenómenos transaccionales que acaban de comentarse ${ }^{40}$.

En este contexto, y sin salir de la LJCA, puede, igualmente, citarse el artículo 29.1, in fine, cuando prevé que la acción procesal allí regulada sólo puede ejercitarse de «no haberse llegado a un acuerdo entre los interesados y la Administración».

En este sentido, y como es propio de las transacciones, pactos o convenios administrativos, el requisito o límite esencial de la conciliación es el de que lo acordado no sea manifiestamente contrario al ordenamiento jurídico ni lesivo del interés público o de terceros, así como que el juicio o proceso se promueva sobre materias susceptibles de transacción y, en particular, cuando verse sobre estimación de cantidad (art. 77 de la LJCA).

Este último inciso informa ya sobre su preferente aplicación práctica en materia de estimaciones de cantidad, como es propio de las transacciones en general, según ya nos consta.

Considerando que la transacción en favor de la Administración es por esencia limitada (en el fondo por el propio principio de legalidad y por la observancia ineludible de los intereses públicos), se entiende que la LJCA exija que los representantes de las Administraciones Públicas demandadas necesitarán la autorización oportuna para llevar a efecto la transacción, con arreglo a las normas que regulan la disposición de la acción por parte de los mismos. «Autorización», por tanto, del Consejo de Ministros, según dispone la LGP (art. 39), en consonancia también con el artículo 88 de la LPC 30/1992, para la terminación convencional.

La conciliación en el proceso administrativo puede verse como un medio que contribuye a buscar solución frente al problema del retraso de los procesos administrativos y consigue, por otra parte, completar o perfeccionar la justicia administrativa.

La conciliación en el proceso administrativo está prevista, por otra parte, en el Derecho comparado (por ejemplo, en el Derecho alemán), y

${ }^{40}$ La conciliación puede verse además en conexión con el allanamiento y con el desistimiento como formas de terminación del proceso; véase sobre aquéllos J. GonZÁlez PÉREZ, «El allanamiento de la Administración», RAP, 27, 1958, pp. 89 y ss. 
en el propio Derecho español la conciliación es conocida en el proceso civil (art. 692 de la LEC) y es una fase procesal típica del proceso laboral; también se ha destacado que la técnica de la reclamación previa al ejercicio de acciones civiles y laborales tiene carácter de «conciliación preprocesal» (STC 120/93), pese a que en realidad no pueda hablarse más que de un semejanza con la conciliación ${ }^{41}$.

Por otra parte, la transacción del artículo 77 de la LJCA tiene un carácter plenamente judicial que hace que se diferencie también de la satisfacción extrajudicial de la pretensión.

Su aplicación práctica puede, no obstante, quedar condicionada por los propios requisitos o presupuestos de la conciliación, que acabamos de estudiar. Además, como medida propuesta de oficio por el propio Tribunal, no es fácil concebir una frecuente aplicación de la conciliación, considerando el «factor tiempo», que repercute sobre la práctica judicial de cualquier orden jurisdiccional y del contencioso en particular. En este sentido, la conciliación se prevé con posterioridad a la demanda y contestación y antes de la sentencia (tal como dice el propio art. 77 de la LJCA), por lo que es presumible que el proceso llegue a una fase en la que lo más realista sea, simplemente, dictar la sentencia.

En cualquier caso, si las partes llegan a un acuerdo que implique la desaparición de la controversia, el Juez o Tribunal dictará auto declarando terminado el procedimiento. Es interesante observar que, en la fase de ejecución de sentencias, la LJCA se haya referido a este supuesto de la conciliación (art. 113):

Transcurrido el plazo de ejecución que se hubiere fijado en el acuerdo que implique la desaparición de la controversia, cualquiera de las partes podrá instar su ejecución forzosa.

Si no se hubiere fijado plazo para el cumplimiento de las obligaciones derivadas del acuerdo, la parte perjudicada podrá requerir a la otra su cumplimiento y transcurridos dos meses podrá proceder a instar su ejecución forzosa.

41 J. L. Piñar Mañas, en J. Leguina Villa/M. Sánchez Morón, La nueva Ley de Régimen Jurídico de las Administraciones Públicas y del Procedimiento Administrativo Común, Madrid, 1993, p. 352; J. A. Santamaría Pastor, RAP, 77, 1975, p. 81; M. F. Clavero Arévalo, en Estudios dedicados al Profesor García Oviedo con motivo de su jubilación, Sevilla, 1954, tomo I, pp. 220 y ss.; D. J. Vera JuRAdo, RAP, 134, 1994, p. 258. 


\section{LOS ARBITRAJES ADMINISTRATIVOS}

\section{Presente y futuro del arbitraje en el Derecho administrativo}

También se va abriendo paso en un plano normativo el arbitraje dentro del Derecho administrativo durante los últimos años ${ }^{42}$.

Encontramos menciones en el artículo 39.1 de la LGP ${ }^{43}$, el artículo 41 de la Ley del Patrimonio del Estado ${ }^{44}, 60.2$ del TR de la LCAP ${ }^{45}$ y especialmente el fundamental artículo 107.2 de la LRJAP-PAC, modificado por la Ley 4/1999, de 13 de enero ${ }^{46}$.

42 Todo ello a pesar de las incertidumbres que plantea, tanto sobre sus límites (como vamos a ver) como sobre su tramitación (V. MAGRo SERVET, «¿Pueden adoptarse medidas cautelares en el procedimiento arbitral?», Actualidad Aranzadi, n. ${ }^{\circ}$ 510, 2001). Sobre el tema también A. LóPEZ ArgUMEDO PIÑEIRO, «Medidas cautelares en arbitraje internacional y nacional», La Ley, 4 de mayo de 2000.

43 Según el citado artículo 39.1 de la LGP, «no se podrá transigir judicial ni extrajudicialmente sobre los derechos de la Hacienda Pública, ni someter a arbitraje las contiendas que se susciten respecto de los mismos, sino mediante Real Decreto del Consejo de Ministros, previa audiencia del de Estado en Pleno».2

Es discutible si este régimen jurídico puede entenderse más que como una regla referida al supuesto concreto de los derechos de la Hacienda como un régimen jurídico de validez general. Para J. M. Chillón Medina/J. F. Merino Merchán, Tratado de arbitraje privado interno e internacional, Madrid, 1991, p. 632, no es posible extender el artículo 39.1 LGP, previsto para la Hacienda Pública, a las distintas relaciones jurídico-administrativas de tipo patrimonial.

44 «Para someter a arbitraje las contiendas que se susciten sobre los bienes o derechos patrimoniales hará falta una Ley que lo autorice.» A efectos de salvar una posible contradicción entre este artículo y el 39 de la LGP téngase en cuenta que el citado artículo 39 LGP se aplica a los derechos de contenido económico o dinerario (arts. 2, 22 y 27 LGP).

45 Este precepto, siguiendo el artículo 61.2 de la LCAP 13/1995, afirma que «el sometimiento a arbitraje se sujetará a los requisitos establecidos en la LGP (art. 39.1 por tanto) o en las correspondientes normas de otras AAPP» (vid. art. 107 de la LRJAP-PAC). Interesante es que dicho art. 61.2 de la LCAP se separó de la prohibición de arbitraje que defendía el artículo 12.2 del Reglamento de Contratación de las Corporaciones locales y propugnaba asimismo el RD de 27 de febrero de 1852 (art. 12); en este contexto puede verse la STS de 11 de marzo de 1980 (Ar. 2146). Véase G. ArIÑo Ortiz, La reforma de la ley de Contratos del Estado, Madrid, 1984, pp. 164 y ss.; R. GÓMEZ-FERRER Morant (dir.), Comentarios a la LCAP, Madrid, 1996, p. 470.

46 «Las Leyes podrán sustituir el recurso de alzada, en supuestos o ámbitos sectoriales determinados, y cuando la especificidad de la materia así lo justifique, por otros procedimientos de impugnación, reclamación, conciliación, mediación y arbitraje, ante órganos colegiados o comisiones específicas no sometidas a instrucciones jerárquicas, con respeto a los principios, garantías y plazos que la presente Ley reconoce a los ciudadanos y a los interesados en todo procedimiento administrativo.»

«En las mismas condiciones, el recurso de reposición podrá ser sustituido por los procedimientos a que se refiere el párrafo anterior, respetando su carácter potestativo para el interesado.»

«La aplicación de estos procedimientos en el ámbito de la Administración Local no podrá suponer el desconocimiento de las facultades resolutorias reconocidas a los órganos representativos electos establecidos por Ley.» 
Como es sabido, el arbitraje, en general, se regula en la Ley de arbitraje $36 / 1988$, de 5 de diciembre ${ }^{47}$.

Los rasgos principales del arbitraje son, conforme a su definición propia, su carácter potestativo, renunciando las partes a la protección judicial (a salvo del recurso que puedan interponer, conforme a ciertos motivos tasados, contra el laudo arbitral ${ }^{48}$ ), nombramiento pactado de los árbitros, existencia de una cuestión litigiosa como objeto del arbitraje.

Con este perfil no es fácil encontrar casos de arbitraje en el Derecho administrativo español. El artículo 107 de la LRJAP-PAC piensa en los arbitrajes como un medio de sustitución de los recursos, por tanto con carácter forzoso ${ }^{49}$. El citado artículo 107 no parece conseguir más que desplazar la competencia en favor de otros órganos no directamente involucrados en la controversia en cuestión.

También se excepciona, por dicho artículo 107, otro criterio esencial del arbitraje desde el momento en que las resoluciones que se dicten podrán ser impugnadas ante la jurisdicción contencioso-administrativa («con respeto a los principios, garantías y plazos...», dice la LRJAP-PAC en su art. 107.2 in fine).

Difícil dilema el de este artículo: si se admite la posibilidad de recurso contencioso-administrativo disminuye la virtualidad del arbitraje, y si se excepciona la posibilidad de recurso contencioso-administrativo puede incurrirse en vulneración de dichos principios y garantías ${ }^{50}$.

47 En este contexto, F. CORdón Moreno, El arbitraje en el Derecho español: interno e internacional, Pamplona, 1995; A. Lorca Navarrete, Comentarios a la Ley del Arbitraje, Madrid, 1991.

48 Sobre esta cuestión es importante la STC 174/1995, que declaró inconstitucional el artículo 38.2.1 de la LOTT, 16/1987, en tanto en cuanto implantaba un arbitraje obligatorio del que sólo se podía prescindir mediante acuerdo unánime de las partes; vid. J. F. MERINO MERCHÁn, en Revista de la Corte Española de Arbitraje, XI, 1995, pp. 223 y ss.; M. MAteo TeJedor, La actividad arbitral de la Administración en el transporte terrestre, Madrid, 1998; J. M. DE LA CuESTA SÁENZ, en Derecho privado y Constitución, 9, 1996, pp. 315 y ss.; M. J. CARAzo LiÉBAnA, en Revista de Derecho Mercantil, 222, 1996, pp. 1305 y ss.

49 En este sentido, SÁNCHEZ Morón entiende que «los procedimientos en cuestión no podrán establecerse como cumulativos u opcionales respecto del recurso ordinario (actualmente de alzada), sino que en el ámbito para el que se establezcan desaparecerá este recurso» («Recursos administrativos», cit., p. 346).

50 Por otra parte, no parece conveniente retornar al modelo de las jurisdicciones especiales. En términos generales, véase sobre esta cuestión F. SOSA WAGNER, Jurisdicciones administrativas especiales, Sevilla, 1977; J. I. Morillo-Velarde PÉrez, «La cláusula de renuncia al recurso y el derecho a la tutela efectiva de los Jueces y Tribunales», $R E D A, 48,1985$, pp. 597 y ss. 
Es preciso dejar claro que actualmente el ordenamiento no prevé casos de arbitraje administrativo a salvo de ciertos arbitrajes interadministrativos ${ }^{51}$.

Tampoco propicia la aplicación del arbitraje administrativo la Ley de arbitraje de 1988 cuando, primero, ignora dicho arbitraje administrativo ${ }^{52}$ y cuando, segundo, exige el requisito de la «disponibilidad de la materia» [arts. 1 y 2.1.b)], requisito que no se cumple en las materias reguladas por el Derecho administrativo.

En general, la posibilidad de admitir el arbitraje se enfrenta en el Derecho administrativo español con principios elementales de obligada consideración, tales como la previsión del sistema contencioso-administrativo como sistema de solución de litigios entre particulares y Administración y de control de la legalidad de la actuación y actos de la Administración Pública (arts. 1.1 y 1.2, art. 2 de la LJCA de 13 de julio de 1998).

En cuanto al debate lege ferenda, el tema o problema principal que plantea el arbitraje es el de la precisión de las materias que pueden quedar sujetas al mismo ${ }^{53}$.

\footnotetext{
${ }^{51}$ Me refiero a la Comisión Arbitral del País Vasco, regulada en el Estatuto de Autonomía del País Vasco, artículo 39, así como a las Juntas arbitrales de resolución de conflictos tributarios interadministrativos: artículo 45 de la Ley 28/1990, de 26 de diciembre, y artículos 23 y 24 de la LO 3/1996, de 27 de diciembre, de modificación de la LOFCA, artículo 39 de la Ley 38/1997, de 4 de agoto. A estos supuestos podría sumarse el previsto en el RD 49/1993, de 15 de enero, que, incorporando la directiva 89/662/CEE, de 11 de diciembre de 1989, sobre Sanidad Animal, prevé que, en caso de conflicto, si las partes lo acordaren, podrán someter el conflicto a la apreciación de un perito que figura en una lista de peritos de la Comunidad, sometiéndose las partes al dictamen que aquél emita. En general, las instituciones comunitarias muestran su interés por la aplicación o instauración de arbitrajes administrativos (puede verse M. Gómez JeNE, El arbitraje comercial internacional en la Unión Europea: la eficacia del laudo arbitral, Madrid, 2000, p. 24), destacando la Resolución del PE sobre el fomento del recurso al arbitraje de derecho para la resolución de los conflictos en el orden jurídico (DOCE C 205, de 25 de julio de 1994, pp. 519 y ss.).

${ }^{52}$ Esta ausencia de mención no sería, no obstante, determinante, ya que puede entenderse como una forma general de dar cabida a todo tipo de arbitraje, administrativo o privado, en la línea de lo que por ejemplo ocurre con la aplicación del Derecho de la competencia a la Administración pública. En este último ámbito está consolidada dicha aplicación precisamente partiendo de la ausencia de un criterio expreso que impidiera la sujeción de la Administración (en sus actividades de tipo económico) al Derecho de la competencia.

${ }^{53}$ En este sentido, el artículo 107.2 de la LRJAP-PAC, cuando admite la sustitución de la vía de recurso administrativo por otros medios, entre ellos el arbitraje, presupone que la «especificidad de la materia así lo justifique».
} 
Se han apuntado en este sentido distintos criterios ${ }^{54}$. El hilo conductor parece estar en la índole patrimonial de la controversia. En este sentido, en el Derecho comparado (Derechos italiano o francés, por ejemplo) llegan a admitirse los arbitrajes administrativos siguiendo el criterio material o funcional de las «cuestiones patrimoniales» ${ }^{55}$. En el propio Derecho español se ha admitido la aplicación de la Ley de arbitraje respecto de la actividad mercantil de entidades administrativas de Derecho privado ${ }^{56}$.

\footnotetext{
${ }^{54}$ Los distintos enfoques o estudios realizados, sobre las materias susceptibles de arbitraje administrativo, parten de la consideración de ciertas actividades («actividades de interés no general», «la actuación discrecional administrativa», la «actuación contractual o convenida», la «actuación de Derecho privado») a efectos de deslindar y admitir la figura del arbitraje administrativo.
}

Sobre esta cuestiones, y sobre el arbitraje en Derecho administrativo en general, M. CORTADA Esteve, «El arbitraje: un medio alternativo en la justicia administrativa», RVAP, 51, 1998); J. M. Chillón Medina/J. F. Merino Merchán, Tratado de arbitraje privado interno e internacional, Madrid, 1991, p. 176; M. L. GonzÁlez-Cú́llar SerRano, «El arbitraje en el Derecho tributario», Revista de Contabilidad y Tributación, 167, 1997, pp. 11 y ss.; J. HorTALA Y VALLVE, «El arbitraje en materia tributaria», Crónica tributaria, 79, 1996, pp. 55 y ss.; F. LóPEz Menudo, «Arbitraje y Derecho Público», Justicia Administrativa, 2, 1999, pp. 13 y ss.; J. C. MARESCA CABOT, «El arbitraje en el Derecho administrativo», Boletín del Tribunal Arbitral de Barcelona, 5, 1994, pp. 57 y ss.; M. J. Montoro Chiner, «Técnicas pre y extraprocesales de resolución de los conflictos urbanísticos», Boletín del Tribunal Arbitral de Barcelona, 9, 1997, pp. 44 y ss.; J. L. ReQuejo Pagés, «La nueva configuración del arbitraje», Revista de la Corte española de Arbitraje, vol. V, 1988-1989, pp. 51 y ss.; J. Rosa Moreno, El arbitraje administrativo, Madrid, 1998; C. SÁenz Casals, «Administración y arbitraje», REALA, 264, 1994, pp. 709 y ss.; J. ToRNos MAs, «El arbitraje en el Derecho administrativo: posibilidad de esta figura jurídica», Boletín del Tribunal Arbitral de Barcelona, 6, 1995, pp. 11 y ss.; del mismo autor su trabajo sobre el particular en $R A P, 136,1995$, pp. 149 y ss.; J. M. TRAYter JiMÉnEZ, «El arbitraje en el Derecho administrativo», RAP, 143, 1997, pp. 93 y ss.

${ }^{55}$ En Francia el arbitraje administrativo termina admitiéndose en materia comercial y actuación patrimonial y de Derecho privado (J. M. AuBY, «L'arbitrage en matière administrative», Actualité juridique, 1985, pp. 1 y ss.); especialmente véanse distintas contribuciones (de diferentes autores) sobre el arbitraje, publicadas en el n. ${ }^{\circ} 1 / 1997$, AJDA; también R. CHAPus, Droit du contentieux administratif, 9 édition, París, 2000, pp. 235 y ss.; P. Durand, «Le reglèment par voie de transaction et d'arbitrage des diférends de droit privé interéssant les établissements publics à caractère industriel ou commercial», Droit social, 1949, p. 325; G. VEDEL, «Le problème de l'arbitrage entre gouvernements ou personnes de droit public et personnes de droit privé», Rev. Arb., 1961, pp. 116. En Italia, igualmente, puede verse G. PANZARINI, «Diritti disponibili, specialità di materie e tipi di arbitrato per la Pubblica Amministrazione», en VV.AA., Arbitrato e pubblica amministrazione, Milán, 1999, pp. 119 y ss.; sobre la alusión a Costa Rica, véase infra.

${ }^{56}$ No sería tanto la actividad de Derecho privado, como la actividad de carácter mercantil, lo que a mi juicio explicaría esta sujeción. Puede verse, por ejemplo, la STS de 6 de marzo de 1987, Ar. 1419, y la resolución publicada en el Boletín del Tribunal Arbitral de Barcelona, de 30 de junio de 1995, asunto 310/95, boletín n. ${ }^{\circ}$ 7, 1995), pp. 107 y ss., en la que fue parte el ente Gestor de Infraestructuras, S. A., empresa pública de la Generalidad de Barcelona.

Por otra parte, considérense los laudos de las juntas arbitrales de consumo, de los Ayuntamientos, impugnables en la jurisdicción civil (por todas, Sentencia de la Audiencia Provincial de Burgos de 5 de enero de 2000, n. $\left.{ }^{\circ} 1 / 2000, A C 2000 \backslash 501\right)$. 
Esta labor de selección o diferenciación de una determinada relación jurídica como de «índole patrimonial» presupone la aplicación de un criterio de carácter material o funcional, ya que la admisión del arbitraje depende del tipo de materia o función, diferenciando las de índole patrimonial a efectos de abrir así paso a los arbitrajes administrativos.

De ahí que pueda advertirse un posible riesgo de extensión de los arbitrajes, con apoyo en la aplicación de unos criterios funcionales que en principio lo hacen factible; según esto, el quid del éxito del arbitraje en el Derecho administrativo estaría en el arraigo en la práctica jurídica de un criterio de carácter material o funcional, es decir, una conversión de ciertos sectores de Derecho administrativo en ámbitos de consideración patrimonial. La cualidad subjetiva (pública o privada) de la entidad sería, entonces, indiferente, por ser en cambio determinante el tipo de función que desempeñe la Administración y que se traduce en un tipo concreto de relación y de controversia jurídicas. Tampoco sería relevante, para negar los arbitrajes, el argumento según el cual la Administración se rige por un principio de competencia incompatible con los arbitrajes o aquel otro en virtud del cual los bienes patrimoniales del Estado y de las personas públicas son indisponibles ${ }^{57}$.

Podría, por tanto, repetirse el fenómeno, que serviría entonces de ejemplo y antecedente a los arbitrajes, de la progresiva aplicación - a ámbitos gobernados tradicionalmente por el Derecho administrativodel Derecho mercantil de la competencia. Sin necesidad de una reforma legal. Pues ha bastado, en efecto, una aplicación en la práctica jurídica (en este caso, esencialmente por el TDC y el TJCE) de un criterio de tipo material o funcional, según el cual la identificación de una actuación de la Administración como mercantil o económica permite la aplicación del citado Derecho de la competencia ${ }^{58}$. Todo ello sin ignorar que, a toda esta evolución subyace, nuevamente, una presión de intereses económicos y

\footnotetext{
${ }^{57}$ En esta línea, J. M. Chillón Medina/J. F. Merino Merchán, Tratado de arbitraje privado interno e internacional, Madrid, 1991, p. 628 y ss., indican que tampoco es válido el argumento según el cual el orden jurisdiccional nacional contencioso-administrativo es el único que puede tener conocimiento en materia de servicios públicos.

${ }^{58} \mathrm{Y}$ cada vez más las actividades son susceptibles de ser consideradas como económicas. La condición del sujeto como Administración Pública cede frente al dato de la identificación de una actividad de tipo económico o mercantil con la consecuencia de la aplicación del Derecho de la competencia en estos casos. Asimismo, dicho Derecho de la competencia, con el apoyo del Derecho comunitario europeo, se ha convertido en un Derecho especialmente importante a la hora de regular aquellos sectores liberalizados que pasan a considerarse en gran parte como mercados y que tradicionalmente eran configurados como servicios públicos regulados casi exclusivamente por el Derecho administrativo. Puede verse S. GonzÁLEZ-VARAs IbáÑEZ, Los mercados de interés general: telecomunicaciones y postales, energéticos y de transportes, Editorial Comares, Granada, 2001.
} 
empresariales que motivan la conversión de lo «público» en «económico» $\mathrm{o} \ll$ mercantil»».

Algo similar podría ocurrir con los arbitrajes si se afianzan en torno a la aplicación de un criterio funcional (actividades de «índole patrimonial»). Aunque por referencia a las transacciones, D. LOPERENA ROTA aporta ciertas reflexiones que ilustran ejemplarmente de esta posible evolución a la que estamos aludiendo cuando llega a decir que «la Administración puede, entre los bienes con los que convenir transaccionalmente, incluir bienes de dominio público». ¿Cómo llegar a admitir esta conclusión? De forma sencilla: "convirtiendo (el bien demanial) en patrimonial, el bien es susceptible de convenio transaccional», "sabiendo (la Administración) que deberá desafectarlo en el procedimiento de aplicación del convenio (transaccional)» ${ }^{59}$.

Otro supuesto: la política de los pactos, el do ut des, de las transacciones, sería admisible en la esfera del empleo público aprovechando la corriente de laboralización (patrimonialización) del régimen funcional. De esta forma sería posible superar «objeciones dogmáticas» tales como «la reserva de Ley de régimen funcionarial», «el principio de legalidad» o el de «legalidad presupuestaria» ${ }^{60}$.

Son éstos ejemplos que ilustran del riesgo, al que nos estamos refiriendo, de cómo - convirtiendo lo público en patrimonial — se da entrada a la aplicación de este tipo de figuras aprovechando un cambio de funcionalidad de ciertos ámbitos de Derecho administrativo.

Ahora bien, podemos plantearnos dos cuestiones a efectos de profundizar en las afirmaciones anteriores. La primera: ¿y no es un obstáculo insalvable la vaguedad, o indefinición, propia del criterio «asunto patrimonial»?

No parece serlo. Así, para el TJCE, el hecho de que pueda ser complejo en un caso determinado observar si la actuación tiene o no carácter «económico» (para aplicar o no el Derecho comunitario de la competencia) no impide llegar a una solución judicial caso por caso. Más bien, es

\footnotetext{
${ }^{59}$ La transacción en la nueva Ley de la jurisdicción contencioso-administrativa, Oñati, 2000, p. 139. El autor pone el ejemplo de la Ley 6/1996, de 8 de junio, de la CA de Madrid, por la que se aprobó un supuesto como el enunciado. Y en torno a la transacción sobre bienes comunales aporta LOPERENA el ejemplo de la Ley foral 6/90, de 2 de julio, de la Administración local de Navarra y el Reglamento de bienes aprobado por Decreto foral 280/1990, de 18 de octubre, cuyos artículos 30 y ss. instan a celebrar convenios transaccionales para evitar pleitos, cediendo el particular una parte del bien a cambio de que reconozca el resto como comunal.
}

${ }^{60}$ La transacción en la nueva Ley de la jurisdicción contencioso-administrativa, Oñati, 2000, pp. 171 a 176. 
ésta una típica función judicial la de ir delimitando este tipo de funciones ${ }^{61}$. Lo mismo podría decirse respecto de los arbitrajes, ya que es una típica función judicial la de decidir, en caso de litigio (más bien cuando se interponga un recurso de nulidad contra el laudo arbitral), cuándo estamos ante una «función patrimonial», es decir, cuando la materia es susceptible o insusceptible de ser sometida a arbitraje administrativo.

Así pues, nuevamente, el Estado reduciría su posición a la esfera de los asuntos de soberanía o imperio, siendo el resto susceptible de dar entrada a las más diversas formas de intromisión de figuras desarrolladas especialmente en el Derecho privado.

De ahí que la pregunta ¿qué ámbitos podrían quedar afectados por el arbitraje administrativo? lleve a fijar como techo o límite máximo el de los asuntos de policía, soberanía, imperio o giro o tráfico administrativo.

El ámbito que puede abarcar el arbitraje se delimitaría por aquellas materias que, por su propio carácter o naturaleza, admiten una versión tanto de Derecho público como de Derecho privado. En estos casos, aunque la versión de Derecho administrativo es perfectamente legítima por ser una de las posibles versiones, no es en cambio la única forma posible de regulación, porque también es admisible y factible una versión de Derecho privado ${ }^{62}$.

El reto del arbitraje es, en conclusión, afianzar un determinado criterio material o funcional que le sirva de aplicación. De esta forma, el arbitraje, aunque aparentemente no esté aplicándose respecto de asuntos administrativos, sino patrimoniales, en realidad o en el fondo se habrá entrometido dentro del campo del Derecho administrativo. Y formalmente el arbitraje no sustituirá a la jurisdicción contencioso-administrativa porque se referirá a ámbitos que previamente se han sustraído a dicha jurisdicción.

\footnotetext{
${ }^{61}$ Puede verse, con ejemplos, S. GonZÁlez-VAras IbáÑEz, El Derecho administrativo europeo, IAAP, Sevilla, 2. ${ }^{a}$ edición, 2002.

${ }^{62}$ De ahí que en cualquier país los asuntos de policía o estrictamente administrativos serán siempre objeto del Derecho público, mientras que otras instituciones administrativas se incardinarán en algunos países en el Derecho público y en otros en el Derecho privado.

Con el arbitraje (figura desarrollada especialmente en el Derecho mercantil para dar satisfacción a agentes económicos) ocurre algo similar a aquello que acontece en todo fenómeno privatizador. La privatización (en cualquiera de sus formas) afecta a ámbitos respecto de los que, conforme a su posible consideración tanto prestacional como económica, es tan legítima y factible una versión jurídico-pública como una versión jurídico-privada. La versión jurídico-administrativa es el servicio público, la versión jurídico-privada de estos mismos sectores es el mercado liberalizado sujeto a regulación.
} 
De hecho, es interesante observar cómo la conversión que, cuando menos en parte, se ha producido durante los últimos años de los viejos servicios públicos en mercados (por ejemplo, las telecomunicaciones, los sectores energéticos, etc.) ha traído consigo la aparición de los arbitrajes como medio esencial de resolución de contiendas ${ }^{63}$.

Mención aparte merece el supuesto del arbitraje administrativo en aquellas parcelas dominadas por el comercio internacional, tal como se hará seguidamente después de terminar, con una última referencia jurídico-comparada, el estudio del arbitraje administrativo interno.

${ }^{63}$ Destacaríamos, pues, este dato de la nueva presencia de arbitrajes como consecuencia de una privatización funcional de los servicios públicos. No obstante, lo cierto es que no estamos tanto ante casos de arbitrajes entre Administración y particulares como ante supuestos de arbitrajes para la resolución de controversias entre los agentes económicos privados que protagonizan estos nuevos mercados de interés general, conforme a su sentido y su configuración fundamentalmente privada. Ello a pesar de que estos arbitrajes sean susceptibles de ser aplicados a la Administración o a sus empresas. El supuesto se asemejaría más bien, por tanto, a aquellos arbitrajes presentes en sectores tales como el transporte o del consumo.

Sobre la función arbitral de la CMT, véase la Ley de Liberalización de las Telecomunicaciones de 1997 (art. 1.Dos.2), así como en el «Reglamento de la Comisión», aprobado por Real Decreto 1994/1996, de 6 de septiembre de 1996. Interesa destacar, sobre la citada CMT, que los laudos que dicte esta Comisión en el ejercicio de su función arbitral tienen reconocidos los efectos establecidos en la Ley 36/1988, de 5 de diciembre, de Arbitraje; su revisión, anulación y ejecución forzosa se acomodarán a lo dispuesto en la citada Ley. No obstante, en puridad, no estamos ante un laudo, sino ante una resolución que pone fin a la vía administrativa y que será recurrible ante la jurisdicción contencioso-administrativa.

En la doctrina española, por todos, J. F. Merino Merchán/M. Pérez-Ugena Coromina, «Función arbitral de la Comisión del Mercado de las Telecomunicaciones», en el libro coordinado por los citados autores, Régimen de las telecomunicaciones, Madrid, 1998, p. 105, quien destaca que la CMT desplaza en su actuación arbitral a Administración y a tribunales. Similar es el planteamiento en Argentina (J. C. CASAGNe, «Los nuevos entes regulatorios», Libro Homenaje al profesor P. Ramella, Buenos Aires, 1994, p. 38).

En el sector postal, las controversias que se susciten entre los operadores postales y los usuarios se resolverán por las Juntas Arbitrales de Consumo, con arreglo a la Ley 26/1984, de 19 de julio, General para la Defensa de los Consumidores y Usuarios. Y cuando los usuarios no se hayan sometido a las Juntas Arbitrales, el órgano competente para resolverlas es el órgano del Ministerio de Fomento que reglamentariamente se determine, pudiéndose impugnar la resolución que se dicte ante la jurisdicción contencioso-administrativa (art. 5 de la Ley postal). En el sector de los hidrocarburos, la Ley de Hidrocarburos crea la Comisión Nacional de Energía, como único órgano encargado de la regulación y vigilancia del mercado energético y de velar por la competencia efectiva (disposición adicional undécima). Y dentro de sus funciones se establecen (en los apartados 9, 12 y 13) las facultades de resolución arbitral de los conflictos que se susciten entre los sujetos que realicen actividades en el sector eléctrico o de hidrocarburos, así como velar por la libre competencia, poniendo en conocimiento del Servicio de Defensa de la Competencia las posibles prácticas colusorias, y resolver los conflictos relativos al acceso de terceros a las redes de transporte y, en su caso, distribución. 


\section{Un ejemplo de regulación de los arbitrajes: el Derecho de Costa Rica}

En estos momentos en que en España se debate la posibilidad de regular normativamente el arbitraje importa hacer mención a la legislación comparada.

En Costa Rica se ha conseguido una regulación en materia de arbitrajes. La propia Constitución reconoce (en su art. 43) que «toda persona tiene derecho a terminar sus diferencias patrimoniales por medio de árbitros, aun habiendo litigio pendiente».

La Ley sobre resolución alterna de conflictos y promoción de la paz social, Ley n. ${ }^{\circ} 7727$, de 9 de diciembre de 1997, en su artículo 2 (solución de diferencias patrimoniales) afirma que «toda persona tiene el derecho de recurrir al diálogo, la mediación, la conciliación, el arbitraje y otras técnicas similares para solucionar sus diferencias patrimoniales de naturaleza disponible».

En el artículo 18 de la misma Ley (arbitraje de controversias) se afirma que «cuando las partes hayan convenido por escrito que las controversias relacionadas con su contrato o relación jurídica se sometan a arbitraje, tales controversias se resolverán de conformidad con la presente ley, sin perjuicio de lo que las partes acuerden por escrito, siempre y cuando no se oponga a las disposiciones prohibitivas o imperativas de esta ley. Podrán someterse a arbitraje las controversias de orden patrimonial, presentes o futuras, pendientes o no ante tribunales comunes, fundadas en derechos respecto de los cuales las partes tengan plena disposición y sea posible excluir la jurisdicción de los tribunales comunes».

Finalmente se reconoce expresamente el derecho a todo sujeto de Derecho público, incluyendo el Estado, a someter sus controversias a arbitraje, de conformidad con las reglas de la presente ley y el inciso 3 de la Ley General de la AP.

En esta Ley General de la AP n. ${ }^{\circ}$ 6227, de 2 de mayo de 1978, se establecen reglas de competencia administrativa. Y en el artículo 66 viene a limitarse el arbitraje administrativo diciéndose que «las potestades de imperio y su ejercicio y los deberes públicos y su cumplimiento serán irrenunciables, intransmisibles e imprescriptibles. Sólo por ley podrán establecerse compromisos de no ejercer una potestad de imperio. Dicho compromiso sólo podrá darse dentro de un acto o contrato bilateral y oneroso». 
Además, la posibilidad del arbitraje se prevé en la legislación especial: artículo 27 (arbitraje administrativo) de la Ley de Expropiaciones n. ${ }^{\circ} 7495$, artículo 61 in fine (recibo de la obra) de la Ley de contratación administrativa (Ley n. ${ }^{\circ} 7494$, de 2 de mayo de 1995); artículo 39 (cláusula arbitral) de la Ley General de Concesión de Obras Públicas con servicios públicos (ley n. ${ }^{\circ} 7762$, de 14 de abril de 1998); artículo 3 del reglamento de la Ley general de concesión de obras públicas n. ${ }^{\circ} 7762$, de 14 de agosto de 1998, publicado en el alcance n. ${ }^{\circ} 27$ a la Gaceta n. $^{\circ} 115$, del 16 de junio de 1998; artículo 53 (arbitraje) de la Ley de promoción de la competencia y defensa del consumidor n. $^{\circ} 7472$, de 20 de diciembre de 1994; artículo 44 de la Ley orgánica del Ministerio de Trabajo y Seguridad social n. ${ }^{\circ} 1860$, de 21 de abril de 1955 , reformada por la Ley n. ${ }^{\circ} 7360$, de 4 de noviembre de 1993.

En la jurisprudencia constan claros testimonios acerca del control judicial sobre los límites de la posibilidad de acudir al arbitraje, como por ejemplo la sentencia de la Sala Primera de la Corte Suprema de Justicia de 9 de marzo de 2001 (ex: 00-000063-004-CA, Res: 000210-F-2001), resolutoria de un recurso de nulidad contra un laudo arbitral por entender una de las partes que la materia sobre la que entendió el tribunal arbitral no pudo haberse sometido a arbitraje: resolución de un asunto objeto de litigio ante un Juzgado contencioso-administrativo relativo a un recurso de lesividad.

En este supuesto, la Sala, después de realizar ciertos razonamientos acerca del control judicial de nulidad de los laudos (próximo al control que propicia un recurso de casación civil limitado al examen de los errores in procedendo, no in iudicando), y después de reiterar el derecho a someter a arbitraje cuestiones patrimoniales y los límites que impone la legislación, sienta que «la competencia para declarar la nulidad de un acto administrativo (a pesar del carácter patrimonial del asunto), mediante el cual el ente actor le canceló a la accionada los derechos laborales como consecuencia de la nota datada 23 de marzo de 1994, es una función pública que por tanto no puede ser delegada de arbitraje».

La propia Sala Constitucional de la Corte Suprema de Justicia ha tenido ocasión de corregir o matizar la regulación legal sobre el arbitraje. La Sentencia de 9 de mayo de 1995, resolutoria de una cuestión de inconstitucionalidad planteada por un Juzgado, sienta que la legislación objeto de litigio es constitucional (Ley 5279, de 27 de julio de 1973, donde se disponía que toda cuestión relativa a contrato-póliza será resuelta por juicio arbitral, excepto en lo que concierne a riesgos profesionales o actos administrativos sin vinculación con contratos de seguro o que no se refieran a cuestiones laborales...), siempre que se interprete en el sentido de que «las controversias entre el Instituto Nacional de Seguros y el asegurado serán resueltas por juicio arbitral cuando así lo elija el asegurado», dejando clara la autono- 
mía de las partes en cuanto a la posibilidad de acogerse a laudo arbitral, ya que «no se podrá impedir a ninguna persona en virtud de esta disposición normativa — ni de cláusula contractual que la reitere- el acceso a los tribunales de justicia para obtener la tutela judicial efectiva».

La misma Sala, en otro pronunciamiento, éste de fecha 23 de agosto de 1992, estima una acción de inconstitucionalidad que afectó ciertos párrafos legales del Código de Trabajo, en especial en tanto en cuanto este Código contemplaba la posibilidad de un «fallo en consciencia, no sujeto a las leyes, reglamentos y directrices gubernamentales».

Otro testimonio importante es el Dictamen de la Procuraduría General de la República de 10 de mayo de 1999 (C-089-99), en el que se responde a la consulta sobre las posibilidades de una entidad de someter a arbitraje las controversias surgidas con los usuarios, por concepto de los servicios que se prestan en el muelle.

El dictamen se basa primeramente en la doctrina científica ${ }^{64}$ para afirmar que, dentro de los servicios públicos, habrá que distinguir entre materias susceptibles y otras insusceptibles de arbitraje (entre las primeras, cuestiones de organización del servicio, de policía, de tarifas, tasas o contribuciones, de control administrativo sobre el concesionario o contratista), enlazando esta doctrina con el artículo 66 de la Ley General de la AP, que, como ya nos consta, considera las potestades de imperio y su ejercicio y los deberes públicos irrenunciables, intransmisibles e imprescriptibles.

A efectos de precisar las materias de índole patrimonial, en torno a las cuales procede el arbitraje según el Derecho costarricense, el dictamen se basa en la doctrina ${ }^{65}$ que defiende que una cuestión patrimonial puede someterse a arbitraje cuando «simultáneamente es de índole patrimonial y objeto de regulación por el Derecho civil, mercantil o laboral» ${ }^{66}$.

El dictamen se detiene igualmente en los límites del arbitraje (principio de legalidad positiva respecto del arbitraje, inexistencia de apariencia

\footnotetext{
${ }^{64}$ Concretamente en el ilustre argentino R. Bielsa, Derecho administrativo, Tomo V, Buenos Aires, 1957, pp. 538 y 539 .

${ }^{65}$ E. Ortiz Ortiz, «Aspectos legales de Concesiones ferrocarrileras», Revista de Ciencias Jurídicas, n. ${ }^{\circ} 27,1966$, pp. 221 y ss.

${ }^{66}$ Una relación detallada y precisa, diferenciando entre distintos casos en que es posible y no es posible el arbitraje administrativo, puede encontrarse en S. ARTAVIA BARRANTES, El arbitraje en el Derecho Costarricense, sin fecha, p. 107; véase también del mismo autor «El Proceso Arbitral en Costa Rica», Tomo I, 1996, p. 45.
} 
de buen derecho del particular, materias excluidas de imperio, motivación).

De esta forma, el dictamen está en condiciones de concluir que la sujeción a arbitraje dependerá (siguiendo los criterios apuntados) de la materia litigiosa que se origine en las relaciones jurídicas entre la empresa gestora y los usuarios ${ }^{67}$.

\section{El éxito del arbitraje administrativo en el ámbito del comercio internacional}

El comercio internacional sufre una enorme expansión que repercute en favor de la aplicación de formas jurídicas de Derecho mercantil, entre ellas el arbitraje ${ }^{68}$.

Posibles postulados de Derecho público que no están en perfecta sintonía con el sometimiento del Estado a arbitrajes internaciones terminan cediendo en favor de la aplicación del arbitraje en estas relaciones jurídicas de este tipo comercial en que interviene la Administración, ante este empuje del mercado especialmente del mercado internacional ${ }^{69}$.

\footnotetext{
Ha llegado a proponerse, después de conocerse el sistema norteamericano y el histórico español de la Constitución de Cádiz, la posibilidad del arbitraje con independencia de la naturaleza pública o privada de la materia, así como una regulación de los aspectos procedimentales del arbitraje en una línea siempre favorecedora a su aplicación (A. MiLANo, «Borrador de propuesta de capítulo relativo al RAC en Derecho administrativo», documento no publicado sin fecha, facilitado por cortesía del autor).
}

${ }^{67}$ A mi juicio, es discutible el requisito según el cual la materia ha de tener naturaleza «jurídico-privada» para poder ser objeto de arbitraje. Incurre en contradicción en mi opinión esta afirmación común: por un lado, se pretende de esta forma excluir del Derecho administrativo el arbitraje, considerando éste posible sólo en torno a las cuestiones de Derecho civil; y por otro lado, las materias que quedan sujetas a arbitraje no terminan siendo sino «materias de Derecho administrativo». Más bien, a mi juicio, los arbitrajes, al igual que ocurre en torno al fenómeno de privatización, podrían referirse a aquellos campos del Derecho que, a pesar de poder estar regulados por el Derecho administrativo, admiten, por su naturaleza, una configuración de Derecho privado. En otros términos, el arbitraje no podrá afectar al núcleo del Derecho administrativo.

${ }^{68}$ Me refiero a los arbitrajes mercantiles internacionales, dejando al margen el supuesto, menos relevante, de los arbitrajes entre Estados, los cuales caen dentro del ámbito del Derecho internacional público y el sistema de resolución de controversias de la OMC (Organización Mundial de Comercio).

${ }^{69}$ Véase para una significación del auge del comercio internacional J. C. FernándEz Rozas (ed.), Derecho del comercio internacional, Madrid, 1996, p. 35. Puede también verse J. M. Chillón Medina/J. F. Merino Merchán, Tratado de arbitraje privado interno e internacional, Madrid, 1991, p. 386, para un estudio de las distintas manifestaciones de la expansión del arbitraje internacional, para las razones de la expansión y sobre el porvenir y tendencias del arbitraje internacional (pp. 387 y ss.). 
En principio, el arraigo del arbitraje en el ámbito de los mercados internacionales se explica ante el hecho de que los grandes inversores están en condiciones de poder imponer a las Administraciones de otros Estados sus propios modos mercantiles y arbitrales de resolución de conflictos, eludiendo los mecanismos nacionales y jurisdiccionales de control que pueden no merecer a aquéllos la suficiente confianza como para someterse a los mismos. Las exigencias de mercado acaban entonces primando sobre los mecanismos del Derecho administrativo. La inexistencia de una jurisdicción internacional donde dirimir los conflictos derivados del tráfico mercantil impulsaría asimismo el arbitraje internacional, a pesar de que ello no impide un interesante fenómeno de formación progresiva de un Derecho común en este ámbito del arbitraje internacional y del comercio internacional en general ${ }^{70}$.

En esta esfera internacional del arbitraje, las justificaciones o reticencias de tipo jurídico, frente al sometimiento de la Administración a arbitraje en el plano del Derecho interno (en esencial la incapacidad de las personas de Derecho público para someterse arbitraje), han terminado por no convencer en un pujante tráfico mercantil internacional que parte de otro tipo de postulados, sin convencer asimismo otras posibles «justificaciones» de carácter propiamente internacional, tales como la inmunidad de jurisdicción en el arbitraje internacional o la inmunidad de ejecución.

Ilustrativa de la evolución apuntada en favor de la superación de las reticencias frente al arbitraje internacional en el plano administrativo ha sido, por ejemplo, la evolución del Derecho francés, en el que, pese a las limitaciones con las que se enfrenta en Francia el arbitraje administrativo ${ }^{71}$, llega a admitirse tanto jurisprudencial como doctrinalmente el arbitraje administrativo internacional 72 .

\footnotetext{
70 A. Rivera, «El arbitraje al alcance de todos», documento sacado de www.inter-mediacion.com/papers/el_arbitraje.htm.

${ }^{71}$ En este sentido, artículo 2.060 del CC y antiguos artículos 1.004 y 83 del Código de Procedimiento Civil. No obstante, por Ley de 5 de julio de 1975 se consiguió admitir los arbitrajes respecto de determinadas categorías de establecimientos públicos de carácter industrial y comercial. A este supuesto habría que añadir la Ley de 19 de agosto de 1986, desplazando el CC y autorizando el arbitraje internacional de determinadas colectividades territoriales y establecimientos públicos, por un interés particular (caso Eurodisneyland). Además, el artículo 1.473.3 del nuevo Código de procedimiento civil francés consagra la capacidad especial del Estado y de sus entidades en lo que concierne al arbitraje internacional.

${ }^{72}$ Los hitos fundamentales en esta evolución han sido las conocidas y divulgadas sentencias de la Corte de Casación, sección civil 1. a de 2 de mayo de 1966, asunto Trésor public c. Galakis y la de 14 de abril de 1964, asunto Onic c. Capitaine due San Carlo, seguidas por la sentencia de la Cour d'appel de Paris de 13 de junio de 1996 (société KFTCIC c. société Icori Estero et autre), en todas ellas admitiendo dicho arbitraje internacional en que era parte el Estado francés.
} 
En el caso de España, aunque nadie parece poner en tela de juicio la validez del arbitraje internacional en el que pueda formar parte la Administración ${ }^{73}$, no es en cambio pacífica la vigencia, en un plano de las exigencias procedimentales, del artículo 39 LGP que ya conocemos ${ }^{74}$. Una norma administrativa con referencia expresa a este tipo de arbitrajes es el artículo 117.3.1 del RD-Legislativo 2/2000, de 16 de junio, por el que se aprueba el TR de la LCAP, a cuyo tenor «en los contratos con empresas extranjeras se procurará, cuando las circunstancias lo aconsejen, la incorporación de cláusulas tendentes a resolver las discrepancias que puedan surgir mediante fórmulas sencillas de arbitraje. En estos contratos se podrá transigir previa autorización del Consejo de Ministros».

Al logro del arbitraje administrativo internacional contribuye la aplicación de las normas fundamentales en la materia que nos ocupa: principalmente, el Convenio de Nueva York de 1958 (sobre el reconocimiento y ejecución de sentencias arbitrales extranjeras), en tanto en cuanto no prevé (y por tanto admite) la capacidad del Estado y de sus entidades para someterse a arbitraje internacional; la Convención de Ginebra de 1961 sobre arbitraje comercial internacional, elaborado bajo los auspicios de la Comisión Económica de las Naciones Unidas para Europa (en cuyo art. 2 reconoce explícitamente dicha capacidad); Convenio de Washington de 18 de marzo de 1965, sobre arreglos de diferencias relativas a las inversiones entre Estados y nacionales de otros Estados, donde se contiene una regulación de la elaboración de listas de conciliadores y árbitros y los respectivos procedimientos de conciliación y arbitraje a que pueden acudir las partes, quedando a libertad de los Estados firmantes tanto sujetarse al mecanismo arbitral como la posible previsión de una vía administrativa previa a dicho procedimiento (art. 26); Reglamento de Arbitraje de la Comisión de las Naciones Unidas para el Derecho Mercantil Internacional (Uncitral), aprobado por Resolución de la Asamblea de las Naciones Unidas 31/98, de 15 de diciembre de $1976{ }^{75}$.

\footnotetext{
${ }^{73}$ Un ejemplo práctico puede ser el recogido en el RD 1525/1988, de 16 de diciembre.

74 E. Artuch Iriberri, en J. C. Fernández Rozas (ed.), Derecho del comercio internacional, Madrid, 1996, p. 477, en sentido negativo a su aplicación; A. L. CAlvo CARAVACA/L. FernándEZ de LA GÁNDARA, El arbitraje comercial internacional, Madrid, 1989, pp. 61 y ss. en sentido positivo; y A. L. Calvo Caravaca/L. Fernández de la Gándara, Derecho mercantil internacional, Madrid, 1993, p. 288.

75 En el artículo 36 del reglamento citado en último lugar se afirma: «si antes de que se dicte el laudo las partes convienen una transacción que resuelva el litigio...». Interesante es, asimismo, el Informe de la Comisión de las Naciones Unidas para el Derecho Mercantil Internacional sobre la labor realizada en su 29 período de sesiones (de 28 de mayo al 14 de junio de 1996). Puede obtenerse en www.uncitral.org/spanish/sessions/unc/unc-29, junto a la Ley modelo de la CNUDMI sobre el arbitraje comercial internacional.
} 
En fin, la realidad mercantil ha superado estos posibles dogmas jurídico-públicos y, más bien, durante los últimos años se han concertado muy numerosos contratos en los cuales los Estados o sus entidades suscriben cláusulas por las que se comprometen a aceptar un arbitraje internacional, admitiendo los arbitrajes administrativos cuando dichos Estados intervienen en el tráfico económico realizando una actividad patrimonial o de gestión.

Por ejemplo ${ }^{76}$, un interesante trabajo de A. PÉREZ HuALDE 77 informa de cuatro arbitrajes internacionales recientes en los que ha participado la Administración Pública en Argentina como consecuencia de la cláusula compromisoria pactada en este sentido entre una empresa extranjera y el Estado de esta República, según la cual las controversias han de dirimirse en el «Centro Internacional de Arreglo de Diferencias relativas a Inversiones», organismo que funciona en el ámbito del Banco Mundial ${ }^{78}$. Los casos se refieren a empresas públicas gestoras de servicios públicos de

\begin{abstract}
Además, deben considerarse distintos Convenios bilaterales ratificados por España que afectan al reconocimiento y ejecución de sentencias arbitrales. Para un estudio de otras Convenciones de carácter multilateral, J. M. Chillón Medina/J. F. Merino Merchán, Tratado de arbitraje privado interno e internacional, Madrid, 1991, pp. 538 y ss.; para el ámbito estrictamente europeo, M. GómEZ JENE, El arbitraje comercial internacional en la Unión Europea: la eficacia del laudo arbitral, Madrid, 2000. En el Mercosur, M. B. Noodt Taquela, Arbitraje internacional en el Mercosur, Buenos Aires, 1999, con cita de los Convenios aplicables a los Estados miembros en sus controversias con los ciudadanos de otros Estados.
\end{abstract}

Por lo que se refiere a las instituciones arbitrales, pueden distinguirse entre aquéllas de carácter nacional (American Arbitration Asociation, London Court of Arbitration, Cámara de Comercio de Zurich, Instituto Holandés de Arbitraje, etc.) y aquellas otras de carácter regional (Reglamento de la Comisión Económica para Europa de la Organización de las Naciones Unidas, Comisión Interamericana de Arbitraje Comercial, Comisión económica para Asia y Extremo Oriente), instituciones de carácter sectorial y corporativo, instituciones de carácter universal (Corte de Arbitraje de la Cámara de Comercio Internacional), junto a otras formas de arbitraje (arbitraje ad hoc y arbitraje semiorganizado).

${ }^{76}$ Otro caso interesante puede ser (por afectar al contrato administrativo más oneroso de la historia de Costa Rica) el contrato para la gestión interesada de los servicios aeroportuarios prestados en el aeropuerto internacional Juan Santamaría.

Se ha dicho que «de un total de 300 procedimientos anuales en el marco de la Cámara de Comercio Internacional casi una tercera parte de ellos tiene lugar con una parte estatal o paraestatal» (J. M. Chillón Medina/J. F. Merino Merchán, Tratado de arbitraje privado interno e internacional, Madrid, 1991, p. 635, nota a pie de página 30, y notas siguientes, con otras referencias sobre el particular).

77 «Las provincias, sus contratos públicos y los Tratados internacionales de protección recíproca de inversiones», La Ley, Buenos Aires, 25 de junio de 2001, Suplemento de Jurisprudencia de Derecho administrativo, pp. 1 y ss. Véase también S. L. RodRíguez, «Hacia un régimen regulatorio en el nuevo milenio», $J A, 6207$, del 16 de agosto de 2000, p. 13.

78 Véase G. S. TAwIL, «Los Tratados de protección y promoción recíproca de inversiones. La responsabilidad del Estado y el arbitraje internacional», La Ley, 2000-D, 1106; también C. A. Manfroni, La Convención Americana contra la corrupción, Buenos Aires, 1997. 
ámbito local que contratan la realización de una determinada prestación en el marco de un servicio público de agua o electricidad con la Administración de este país ${ }^{79}$.

Esta casuística lleva a decir que «el procedimiento que surge del Tratado afecta, sin lugar a dudas, el esquema de control judicial de nuestros contratos administrativos provinciales en tanto en cuanto los mismos ahora, cuando incluyen inversiones extranjeras, pueden ser revisados en una instancia que excede los límites nacionales» ${ }^{80}$.

Así pues, tanto en España como en otros Estados próximos se discute especialmente sobre una figura, el arbitraje, cuyos límites no están aún definidos con claridad. He pretendido aportar algún rayo de luz sobre la materia, advirtiendo de su insatisfactoria regulación y de su posible evolución, y habrá que esperar para observar el desarrollo jurídico que aquéllos alcancen en la práctica administrativa. Aunque sólo sea por la posible necesidad de fijar límites jurídicos conviene, ante todo, desechar actitudes apriorísticas que quieran llevarnos a ignorar la aplicación que se esté haciendo de ciertas figuras dentro de parcelas de actuación que afecten a la Administración pública.

\footnotetext{
79 Véase D. LeCuona, «Arbitraje internacional sobre la concesión del servicio de agua y cloacas de la Provincia de Tucumán. Estado de la cuestión a agosto de 1998», ED, 180-1213.

${ }^{80}$ A. PÉREZ Hualde, «Las provincias, sus contratos públicos y los Tratados internacionales de protección recíproca de inversiones», La Ley, Buenos Aires, 25 de junio de 2001, Suplemento de Jurisprudencia de Derecho administrativo, p. 4.

En el caso que comenta este autor (D. C. 2000/11/21, caso n. ${ }^{\circ}$ ARB/97/3, Compañía de aguas del Aconquija, S. A., y otra contra República Argentina), cuyo laudo puede consultarse en La Ley, 2001-A,230 o en inglés en www.worldbank.org/icsid, el Tribunal arbitral no entró en el fondo del asunto por entender que era necesario haber acudido con anterioridad a la jurisdicción nacional argentina por el hecho, sólo por este hecho, de haberse pactado así en el contrato administrativo objeto de litigio.
} 
REAL-2001, núm. 286-287. GONZÁLEZ-VARAS IBÁÑÉZ, SANTIAGO. LA IRRUPCIÓN DE LAS NE...

REAL-2001, núm. 286-287. GONZÁLEZ-VARAS IBÁÑÉZ, SANTIAGO. LA IRRUPCIÓN DE LAS NE... 